\title{
EXPLAINING THE PATTERN OF SECURED CREDIT
}

\author{
Ronald J. Mann
}

"I would say that there's a lower cost in an unsecured situation because of all the brain damage in going out and getting appraisals and all that other bullshit [in a secured situation], where in an unsecured deal you just do the deal and you get the money ...." Telephone Interview with William S.H. Stuart, President, WSHS Enterprises, Inc. (July I2, r995).

\section{TABLE OF CONTENTS}

I. A Decision-Based Model of the Borrowing Decision ............. 634

II. The Benefits and Burdens of Secured Credit .................. 638

A. The Benefits: Why Would a Borrower Ever Secure Its Debt? .......... 638

I. Direct Advantages: Enforcing Payment ..................... 639

2. Indirect Advantages: Before Collection $\ldots \ldots \ldots \ldots \ldots \ldots \ldots \ldots \ldots, 639$

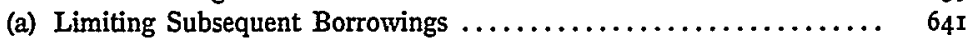

(b) Enhancing the Borrower's Incentive to Pay $\ldots \ldots \ldots \ldots \ldots \ldots \ldots, 645$

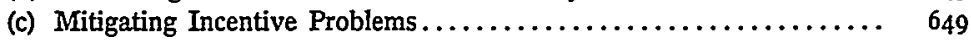

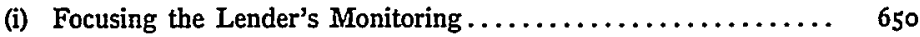

(ii) Enhancing the Effectiveness of Loan Covenants ........... $65 \mathrm{I}$

(iii) Effects of Leverage............................ 655

(iv) Fostering Exclusive Lending Relationships ............ 656

B. The Burdens: Why Wouldn't a Borrower Always Secure Its Debt? ........ 658

1. The Costs of Closing the Transaction $\ldots \ldots \ldots \ldots \ldots \ldots \ldots \ldots \ldots, 659$

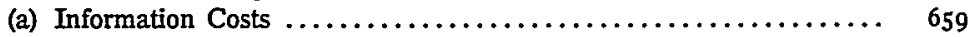

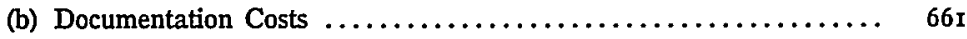

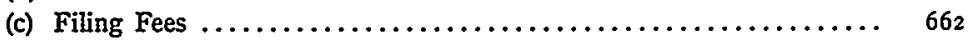

2. The Costs of Administering the Loan $\ldots \ldots \ldots \ldots \ldots \ldots \ldots \ldots \ldots, 663$

(a) The Incentives of the Lender $\ldots \ldots \ldots \ldots \ldots \ldots \ldots \ldots \ldots \ldots, 664$

(b) The Inevitable Costs of Leverage....................... 664

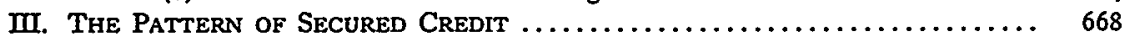

A. Unsecured Debt of Strong Companies ........................ 668

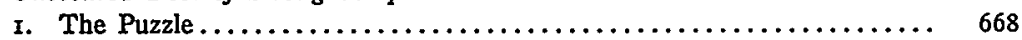

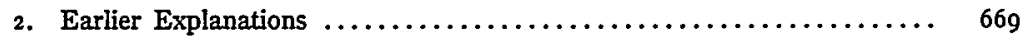

3. Decision-Based Analysis . ............................ 671

B. Long-Term Debt and Collateral ............................ 674

C. The Unsecured Debt of Inventory Suppliers.................... 677

IV. Conclusion: Where Do We Go from Here?................... 682 


\title{
EXPLAINING THE PATTERN OF SECURED CREDIT
}

\author{
Ronald J. Mann*
}

\begin{abstract}
Granting collateral to secure loans is a prominent feature of the U.S. economy, but, surprisingly, we do not understand how borrowers and lenders decide whether to engage in a secured or an unsecured transaction. In this Article, Professor Mann argues that existing theories of secured lending are inadequate because the theories' predictions have not been tested against empirical data. To understand the actual pattern of secured credit, Professor Mann interviewed more than twenty borrowers and lenders in various sectors of the economy. Based on the evidence gathered in these interviews, as well as on preexisting empirical studies, this Article develops a model of the borrower's decision to grant collateral that focuses on the borrower's perceptions of the costs and benefits of secured and unsecured transactions. Granting collateral lowers the aggregate costs of a lending transaction by lowering the pre-loan perception of the risk of default. Secured credit can do this not only by increasing the lender's ability to collect the debt forcibly through liquidation of the collateral, but also in less direct ways: by decreasing the borrower's ability to obtain subsequent loans; by increasing the lender's leverage over the borrower's activities; and by repairing the loan-induced differentiation of the incentives of the borrower and the lender. Conversely, a grant of collateral can increase the costs of a lending transaction by increasing the costs of entering the transaction as well as the costs of administering the loan. In the Article's final section, Professor Mann uses the decision-based model to explain three separate aspects of the pattern of secured credit: the relatively infrequent use of secured credit by companies with strong financial records, the relation between the use of collateral and the duration of the debt, and the apparently low rate of retention of security interests by suppliers.
\end{abstract}

* Associate Professor, Washington University School of Law, St. Louis, and Research Fellow, Olin Center for Business, Law, and Economics. I dedicate this project to my wife, Allison, whose patient encouragement and persistent criticism are responsible not only for my completion of the Article, but also for innumerable substantive improvements of its contents. I also thank Barry Adler, Stuart Banner, Bernard Black, Jim Bowers, Mark Gergen, Steve Harris, Tom Jackson, Marcel Kahan, Dan Keating, Jim Krier, Lynn LoPucki, Nancy Rapoport, Bob Rasmussen, George Triantis, Elizabeth Warren, Jay Westbrook, and Ben Wilner for comments on earlier versions of this project. I thank Mark Ramseyer and my colleague Curtis Milhaupt for assistance in locating and translating Japanese materials. My thoughts on this topic also benefited from the discussion in workshops at the University of Michigan Law School, the University of Texas School of Law, and the Olin Center for Business, Law, and Economics. Finally, I acknowledge Norman Beck, Mike Bloomquist, Bob Droney, and David Royster for their able research assistance.

I am indebted to the individuals who took time away from their productive affairs to aid my academic pursuits. Leaving aside those who requested anonymity, the individuals and their companies are as follows: Sonia W. Hamstra and Gordon S. Massie (American General Corporation); Jocelyn Sears (American General Realty Advisers, Inc.); William J. Kimmins, Jr. (Anheuser-Busch Companies, Inc.); Richmond W. Coburn and Clyde F. Wendel (The Boatmen's National Bank of St. Louis); Naran U. Burchinow, Richard Greco, and James C. Meals (Deutsche Financial Services Corporation); R.O. Wirengard (Eveready Battery Company, Inc.); Andrea J. Dunn and David R. Edlund (Hewlett-Packard Company); Harry C. Mueller (Mercantile Bank of St. Louis N.A.); Joe DeKunder and Cynthia C. Sanford (NationsBank of Texas, N.A.); William S.H. Stuart (WSHS Enterprises, Inc.); Carl W. Evans (Texas Pneumatic Tools, Inc.); and Joseph W. Robertson, Jr. (Weingarten Realty Investors). 
Granting collateral to secure loans is a dominant feature of this country's commerce: domestic lenders currently hold about two trillion dollars in secured debt. ${ }^{1}$ At present, policymakers are updating the legal systems under which creditors take real and personal property as collateral. For example, the American Law Institute recently adopted a Restatement of Mortgages that sets forth the principles governing security interests in real property. ${ }^{2}$ Similarly, the National Conference of Commissioners on Uniform State Laws and the American Law Institute are nearing completion of a lengthy project to update Article 9 of the Uniform Commercial Code, which governs security interests in personal property. ${ }^{3}$

Although grants of collateral are prominent in our economy and in the pages of academic journals, ${ }^{4}$ we know astonishingly little about the most fundamental question regarding secured lending: why people do it. The limitations of our understanding have been evident since Alan Schwartz's I98I article in the Joumal of Legal Studies questioned the efficiency of secured credit. 5 Schwartz argued that most of the obvious explanations for secured credit suggest that rational borrowers would secure their debt to the greatest degree practicable. ${ }^{6}$

1 I derived the two trillion dollar figure by aggregating conservative estimates of outstanding secured debt for federally insured depository institutions, insurance companies, and nonbank finance companies. See Federal Deposit Ins. Corp., Statistics on Banking C-6 tbl.RC-4, E-6 tbl.RC-I4 (I995) (reporting that federally insured depository institutions at the end of 1995 held a total of \$r.6 trillion in loans secured by real estate); BOARD OF GOVERNORS OF THE FED. RESERve Sys., ANnual Statistical Digest: 1994, at $7 \mathrm{I}$ tbl.33 (I995) (reporting that life insurance companies held over $\$ 215$ billion of mortgage debt at the end of 1994); Michael D. Sherman, Survey of Asset-Based and Other Competitive Lending Activities, THE SECURED LENDER, Nov.-Dec. I993, at I8, I8 (reporting estimates of asset-based lending by commercial finance companies in 1992 ranging from $\$ 96$ to $\$ 3$ Io billion).

2 The American Law Institute approved the final draft in May 1996. See American Law Institute Nears Finish Line on Lawyer Ethics, Product Liability Projects, 64 U.S.L.W. 2739, 2739, 2747-48 (May 28, 1996).

3 See U.C.C. Revised Art. 9 (Discussion Draft I9g6).

4 During the last two years, Article 9 has been the focus of two major law review symposia. See Symposium on the Revision of Article $g$ of the Uniform Commercial Code, 80 VA. L. REV. I783 (1994); Symposium: "Managing the Paper Trail": Evaluating and Reforming the Article 9 Filing System, 79 MrNN. L. Rev. 519 (1995). As the following discussion suggests, I analyze the empirical question of why people use secured credit, rather than the normative question of whether we should let them.

5 See Alan Schwartz, Security Interests and Bankruptcy Priorities: A Review of Current Theories, Io J. LEGAL STUD. I, 7-30 (Ig8I). Schwartz's article relied heavily on an earlier article published by Tom Jackson and Tony Kronman. See, e.g., id. at ro n.27, II n.28, 23 n.4I (citing Thomas H. Jackson \& Anthony T. Kronman, Secured Financing and Priorities Among Creditors, 88 YALE L.J. II43 (I979)). But Jackson and Kronman did not ignite much controversy because they did not express any significant doubts about the general desirability or efficiency of secured credit.

6 See Schwartz, supra note 5, at 24-25 (claiming that explanations that "predict[] that, other things equal, firms will issue as much secured debt as they can" are inaccurate given that "[f]irms ... often seem not to issue as much secured debt as their assets would justify"). 
Observing that many borrowers do not secure all of the debt that they can, Schwartz posed what Barry Adler has labeled the "ubiquity puzzle" of secured credit: "The puzzle is that secured credit appears valuable but is not ubiquitous."

Since the publication of Schwartz's article, numerous scholars have taken up his challenge to explain why secured lending is - or is not - an efficient practice. ${ }^{8}$ Although some scholars who have written in the area might disagree, it is fair to say that none of those attempts has succeeded. 9 The central problem with the existing explanations is methodological. Because previous commentators generally have focused on the efficiency question, they have, with very few exceptions, ${ }^{10}$ approached the problem from the top down. Specifically, most scholars have started their analysis with reductionist factual assumptions and then applied abstract economic tools to build a theoretical superstructure upon those assumptions. ${ }^{11}$ Only at the end of the process, if

7 Barry E. Adler, An Equity-Agency Solution to the Bankruptcy-Priority Puzzle, 22 J. LEGAL STUD. 73, 74 (1993). Adler comments: "The solution should address this 'ubiquity puzzle' directly." Id.

8 For synopses of the literature, see Lynn M. LoPucki, The Unsecured Creditor's Bargain, 80 VA. L. REv. 1887, 1892-96 (1994), and Paul M. Shupack, Solving the Puzzle of Secured Transactions, 4I RUTGERS L. REV. 1067, 1073-83 (r989).

9 Alan Schwartz certainly has rejected the attempts to date, taking up the cudgel once every five years or so to critique other scholars' efforts to solve the puzzle. See Alan Schwartz, The Continuing Puzzle of Secured Debt, 37 VAND. L. REV. IO5I, I055-66 (1984) [hereinafter Schwartz, The Continuing Puzzle] (taking issue with Saul Levmore's monitoring and free-ridership explanation for the lack of secured credit and with J.J. White's interest rate and risk-aversion theories for the lack of secured credit); Alan Schwartz, $A$ Theory of Loan Priorities, i8 J. LEgal Stud. 209, 243-47 (1989) [hereinafter Schwartz, Theory] (rejecting several authors' suggestions that secured credit serves a signaling function); Alan Schwartz, Taking the Analysis of Security Seriously, 80 VA. L. REv. 2073, 2077-86 (1994) [hereinafter Schwartz, Taking Analysis Seriously].

10 Lynn LoPucki emphasizes the absence of empirical support for prior analyses of the problem. See LoPucki, supra note 8, at I894 n.23 (characterizing the actual pattern of secured and unsecured debt as the glass slipper from the Cinderella story and criticizing prior scholars for manipulating "the shape of the slipper" in order to allow their theories to slip into it). Although his article emphasizing that point does not attempt to explain the pattern of secured and unsecured debt, he addresses aspects of the empirical pattern of secured credit in a number of places. See, e.g., id. at 1896 . I address those portions of his analysis that are relevant to my discussion. See infra 643-44, 670-71, note 219.

11 For example, Barry Adler and George G. Triantis have written two of the most promising recent articles in this debate. See Adler, supra note 7; George G. Triantis, Secured Debt Under Conditions of Imperfect Information, 2I J. LEGAI, STUD. 225 (1992). Both scholars offer lucid and sophisticated theoretical expositions of why parties should issue secured and unsecured debt, but make no attempt to determine whether the theories are consistent with the observed patterns of secured and unsecured debt. George Triantis, for example, notes that his two theories produce "predictions that conflict" with each other, but he does not state which prediction is correct. Id. at 256 . He attempts to resolve the "tension ... by recognizing that the two theories . . . operate in different contexts," but does nothing to explain what those contexts might be or what factors might lead to the operation of one theory instead of the other. Id. Barry Adler closes his article with a section titled "Predictions and Evidence," Adler, supra note 7, at 96, but the only evidence that he considers is a single empirical study, see id. at 97 n.86. He does offer some specific 
at all, have these scholars made any serious effort to compare their theories about the efficiency justifications for secured credit with the actual pattern of secured credit. At that point, when the theory already has been developed, the consideration of empirical evidence almost inevitably becomes a cursory afterthought instead of an integral part of the analysis.

As a result, none of the existing theories explains the actual pattern of secured credit in the economy. ${ }^{12}$ The signaling hypothesis, which Alan Schwartz frequently discusses, provides one of the clearest examples of this incongruity. ${ }^{13}$ The hypothesis predicts that the strongest companies will be more likely to grant collateral as a way to signal their strength and ability to pay. ${ }^{14}$ That prediction, however, is inconsistent with the most well-established aspect of actual practice: the strongest companies in our economy ordinarily do not secure their debt. ${ }^{15}$

predictions, but he leaves for others the empirical research needed to test those predictions. See id. at 97-98 (offering predictions as well as proposals for future empirical study). As I explain below, the available empirical evidence, including the information that I have collected, strongly rebuts Adler's conclusions. See infra pp. 669-71,

12 Jim Bowers explains:

In many cases, the resulting theories predict that debtors will do all or none of their borrowing on a secured basis, so that the validity of the analysis is undermined by the empirical observation that firms tend to employ a mix of secured and unsecured borrowing. Others suffer from a shortcoming of scope. While they may explain certain special types of security devices, they do not justify other sorts of secured borrowing actually observed.

James W. Bowers, Whither What Hits the Fan?: Murphy's Law, Bankruptcy Theory, and the Elementary Economics of Loss Distribution, 26 GA. L. REV. 27, 60 (I991) (footnotes omitted); see also F.H. Buckley, The Bankruptcy Priority Puzzle, 72 VA. L. REv. 1393, I419 (I986) ("These [existing] theories, however, appear to prove too much; they fail to explain why firms are not all secured to the hilt."); Schwartz, The Continuing Puzzle, supra note 9, at ro6r (arguing that J.J. White's theory must be incorrect because it predicts that "debtors always would borrow on a secured basis until they ran out of free assets"); Robert E. Scott, A Relational Theory of Secured Financing, 86 CoLUM. L. REv. 9or, 902 (I986) (noting the "inability [of existing explanations] to explain completely the patterns of secured and unsecured credit that are actually observed").

13 See Schwartz, supra note 5, at 14-2I (discussing the signaling hypothesis); Schwartz, Theory, supra note 9 , at $245-46$ (same).

14 The "signaling" explanation is essentially identical to the conventional explanation for secured credit in the finance literature, which states that secured credit is a device used to remedy the problem of "asymmetric information" - that is, the borrower's possession of greater knowledge about the prospects for future performance. See, e.g., STUART I. GREENBAUM \& ANJAN V. Thakor, Contemporary Financial InTERMEdiation 225-27 (I995); David Besanko \& Anjan V. Thakor, Competitive Equilibrium in the Credit Market Under Asymmetric Information, $42 \mathrm{~J}$. ECON. THEORY 167,168 (1987) (summarizing the conclusion that asymmetric information causes "low-risk borrowers [to] put up more collateral than high-risk borrowers").

15 The general absence of secured debt from the balance sheets of the most creditworthy companies is commonly asserted as an anecdotal matter. See, e.g., Homer Kripke, Law and Economics: Measuring the Economic Efficiency of Commercial Lave in a Vacuum of Fact, I33 U. PA. L. REV. 929, 969-70 (1985). The most persuasive empirical evidence appears in Berger and Udell's I9go article. See Allen N. Berger \& Gregory F. Udell, Collateral, Loan Quality, and Bank Risk, 25 J. MONETARY ECON. 2I, 27-40 (1990) (examining Federal Reserve data on over one million business loans and concluding that collateral is more frequently granted on riskier loans); see also 
This Article responds to the failure of the existing theories by rejecting the methodological approach that underlies the existing debate. Theorizing about the efficiency of secured credit without having even a rough idea of the situations in which parties use secured credit is a pointless exercise. Moreover, whatever the value of purely theoretical assessments of the efficiency of secured credit, understanding the reasons that motivate parties to use secured credit in practice is useful for the designers of the legal systems that permit - and limit - its use. As policymakers struggle with the propriety of a legal system that has fostered a dramatic growth in the amount of secured credit, ${ }^{16}$ discovering exactly why parties are using secured credit is more important than ever. Thus, in contrast to the top-down analysis of previous scholars, who have started with the macro-question - whether secured credit is an efficient institution - this Article works from the bottom up, building on a firm empirical investigation of the microquestion - what motivates parties to choose between secured and unsecured credit. Until we can explain those motivations, we cannot intelligently evaluate how the legal system should respond to parties' use of secured credit.

This goal drives my analysis in two directions that differentiate it from the work of prior commentators. First, understanding the pattern of secured credit requires an examination of the perceptions of the players in the lending market that lead them to secure (or refrain from securing) their lending transactions. Decisions about securing credit can be understood only from the perspective of the decisionmaker. And what is relevant to the decisionmaker is not the actual return on a loan, but the return anticipated at the time that the decisionmaker decides whether to enter the transaction. Thus, an understanding of the decisionmaker's perspective can come only from a focus on how the decisionmaker perceives the costs and benefits of secured and unsecured credit before the loan is made.

Second, because the ultimate goal is to understand why some borrowers choose secured credit and others do not, an examination of the wide variety of contexts in which the decisions are made is crucial. The nature of the decisions in question - complex, multifactored, and

Scott, supra note 12, at 940 (reporting earlier studies that indicate that "[m]ost secured debt is issued by relatively small, young and growing firms"). See generally infra section III.A.I (discussing empirical evidence). Several scholars have argued that the inconsistency of the signaling hypothesis with the observed pattern demonstrates the fallacy of signaling as an explanation for the use of secured credit. See, e.g., LoPucki, supra note 8, at I926 n.149 ("That loans should be unsecured when they are to the largest, financially strongest firms is not particularly startling. But it does dispatch the 'signaling' theory from the economic literature . . . ."); James J. White, Efficiency Justifications for Personal Property Security, 37 VAND. L. ReV. 473 , 477 (1984).

16 See, e.g., Lynn M. LoPucki, The Death of Liability, I06 YALE L.J. I, I8-I9 (1996) (describing the expansion of secured debt fostered by Article 9 ). 
strategic - suggests that neither abstract theoretical analysis nor the relatively limited existing statistical information captures the richness and ambiguity of the actual relations. To build on the existing empirical data, I collected anecdotal information about the actual operation of the commercial lending market by interviewing twenty-three individuals employed by borrowers and lenders in different sectors of that market. ${ }^{17}$

This Article is not the first to use interviews with borrowers and lenders to learn about the market for secured credit. Both Bob Scott and Alan Schwartz have relied on interviews with market participants in their work; Scott and Schwartz appear, however, to have limited their interviews to large commercial lenders and (even less usefully) their lawyers. ${ }^{18}$ Given the immense variety of transactions in the lending market, interviews limited to any one sector seem unlikely to shed much light on the overall pattern.

I constructed a set of interviews designed to mirror as closely as possible the lending market as a whole. On the borrowing side, I viewed borrowers as differentiated by the size of the company, the company's access to publicly traded debt, and the company's line of business. Accordingly, I interviewed responsible individuals at large and small companies, ranging from two publicly traded Fortune roo companies $^{19}$ to several small, closely held companies (including one that has never turned a profit). ${ }^{20}$ I also interviewed several borrowers that borrow exclusively in the private debt market, ${ }^{21}$ a borrower in

17 The interviews typically lasted from 45 minutes to an hour. I proceeded loosely in accordance with a script of questions I prepared in advance, but allowed the interview subjects free rein to lead the interview to topics that they found important. Although I used some of the same questions for many of the interviews, I tailored the scripts to each interview to focus on the likely experience of the subject. To help ensure a spontaneous response, I did not provide the scripts of questions to the interview subjects in advance, but I gave them a general idea of the range of topics that I planned to cover. If practical, I conducted the interviews in person; in several cases, however, I conducted them by telephone. To ensure the accuracy and verifiability of the conclusions that I draw in this Article, I recorded and transcribed all of the interviews. Copies of the transcripts are on file with the Harvard Law School Library and the author. I also obtained standard loan documents from a number of the lenders whom I interviewed; copies of these documents also are on file with the Harvard Law School Library and the author. In 6 of the 23 interviews, the interview subjects requested anonymity. The transcripts for those interviews have been altered to preserve the anonymity of the subjects.

18 See Schwartz, Theory, supra note 9, at 217 n.I7; Scott, supra note 12, at 939 .

19 Anheuser-Busch Companies, Inc. and Hewlett-Packard Company.

20 Five of the borrowers are closely held: WSHS Enterprises, Inc., Texas Pneumatic Tools, Inc., an anonymous mall developer, an anonymous pharmaceutical company, and an anonymous shopping center developer. The pharmaceutical company has not yet turned a profit. See Telephone Interview with Anonymous President of Pharmaceutical Company (July 17, 1995) [hereinafter Pharmaceutical Company Interview] (transcript at 7 , on file with the Harvard Law School Library).

21 WSHS Enterprises, Inc., Texas Pneumatic Tools, Inc., and the anonymous mall developer, anonymous pharmaceutical company, and anonymous shopping center developer. 
the process of issuing its first public debt issue, ${ }^{22}$ and several borrowers that are active in the public debt markets. ${ }^{23}$ Finally, I interviewed individuals operating in various lines of business, including real estate, ${ }^{24}$ pharmaceuticals, ${ }^{25}$ industrial tooling, ${ }^{26}$ manufacturing, ${ }^{27}$ and computer technology and service. ${ }^{28}$ On the lending side, I interviewed representatives of each of the major types of institutional lenders in our economy - insurance companies, ${ }^{29}$ banks, ${ }^{30}$ and asset-finance companies $^{31}$ - as well as several noninstitutional lenders who extend significant amounts of trade credit to their customers. ${ }^{32}$

Because of the relatively small sample size, the results of my interviews are not useful for producing statistically significant numerical results. ${ }^{33}$ Nevertheless, the results have considerable value. First, my sample is sufficiently representative to justify confidence in areas in which I obtained a consensus from the broad range of individuals whom I interviewed. Second, even in situations in which I obtained evidence from one or only a few individuals, this evidence still has great value as direct evidence of the perceptions of the individuals who actually enter into the transactions the Article examines. Given a choice between the untested predictions of abstract economic models

22 The anonymous office building developer.

23 Anheuser-Busch Companies, Inc., Hewlett-Packard Company, Weingarten Realty Investors, and the anonymous manufacturer.

24 Weingarten Realty Investors and the anonymous mall developer, anonymous office building developer, and anonymous shopping center developer.

25 The anonymous pharmaceutical company.

26 Texas Pneumatic Tools, Inc.

27 Anheuser-Busch Companies, Inc. manufactures beer, Hewlett-Packard Company manufactures computers and related equipment, and the anonymous manufacturer produces a variety of electronic and related products.

28 WSHS Enterprises, Inc.

29 I interviewed three different officers in the investment arm of American General Corporation: one who manages investments in private and public placements (Gordon S. Massie), one who invests in privately and publicly traded real estate securities (Sonia W. Hamstra), and one who supervises loan administration for a related entity (Jocelyn Sears).

30 The interview subjects make a wide variety of bank loans, including small-business loans (Joe DeKunder), middle-market loans (the anonymous middle-market banker), construction loans (Richmond W. Coburn), general commercial loans (Harry C. Mueller), and large corporate loans (Clyde F. Wendel).

31 At Deutsche Financial Services Corporation, I spoke to the director of portfolio credit, who supervises large transactions (James C. Meals), and also to the credit manager of the local St. Louis region, who has responsibility for much smaller transactions (Richard Greco).

32 I spoke to a trade credit administrator at Eveready Battery Company, Inc. (R.O. Wirengard) and at Hewlett-Packard Company (Andrea I. Dunn).

33 I also recognize that any attempt to use interviews to evaluate complex environments is subject to the problem that the interview subjects may not be able to explain the motivations for their actions to the interviewer. See Lynn M. LoPucki, Legal Culture, Legal Strategy, and the Law in Lawyers' Heads, go Nw. U. L. REV. I498, I548 (1996) (suggesting that the "principal limitation" of interviews as a technique for evaluating strategies "is that real people may not have good analyses of their own actions or, if they do, may not be very good at explaining them"). 
and the experience of individuals who have real money at stake in the lending market, the lessons of experience should prevail.

Working from the base of data gathered in those interviews, this Article presents the most comprehensive explanation yet offered of the factors that influence the pattern of secured credit. Most previous work analyzing the reasons that parties choose secured credit has attempted to provide a unified theory for secured credit, using a single consideration to explain all or most of the manifestations of secured and unsecured credit. ${ }^{34}$ The empirical evidence presented in this Article casts grave doubt on most of the one-factor perspectives advocated by previous commentators; it also suggests that no such perspective can succeed. This Article argues that no single factor can capture the multiple and interrelated considerations that motivate borrowers and lenders as they structure their various transactions.

Starting from that multivariate perspective, Part I spells out the assumptions on which the Article's analysis rests and sets out a method of organizing the relevant considerations: a model of the borrower's decision to enter a lending transaction that is based on the premise that the borrower will structure its borrowing to minimize the joint costs of the borrower and the lender. Part II uses that decisionbased model to outline the reasons why borrowers might or might not wish to secure their loan transactions, presenting a series of different factors and developing the considerations that explain the puzzles discussed in Part III of the Article.

Because of the empirical underpinnings of this Article, Part $I I$ provides significantly more detail than previous scholarship about the mechanisms by which secured credit can lower and raise the costs of lending transactions. Specifically, section II.A explains how a grant of collateral can lower the parties' pre-loan assessment of the likelihood of nonpayment by increasing the lender's ability to coerce payment if the borrower does not pay voluntarily. Less directly, the collateral also enhances the borrower's incentive to pay voluntarily and lessens the differentiation of incentives between the borrower and the lender. In addition to creating these benefits for the parties, however, granting collateral also can impose costs. Section II.B argues that granting collateral increases the costs of entering the transaction (especially for publicly traded borrowers) as well as the costs that the parties incur during the course of loan administration. The differing incentives of the parties are the source of the administrative costs: a lender looks to its borrowers for stability, not growth, and it is costly for borrowers to

34 See, e.g., Adler, supra note 7, at 89-95 (arguing that unsecured credit is used to provide monitoring for dispersed equity investors); Scott, suppra note 12, at 916-19 (arguing that secured credit is used to foster exclusive lending relationships); see also LoPucki, supra note I6, at I4-I9 (suggesting that secured credit is used to render borrowers judgment proof). 
submit their decisionmaking to the supervision of a party not interested in maximizing the borrower's long-term profitability. The costs of that supervision - costs that prior scholars have largely dismissed or ignored - constitute a significant reason for parties to choose not to use secured credit.

Finally, Part III applies the Article's decision-based model to three common puzzles about the pattern of secured credit. First, Part III addresses the most well-documented fact about the pattern: the general absence of secured credit from the balance sheets of the most financially sound companies. Previous scholars have offered a variety of theoretical explanations for that phenomenon. None of these theories, however, satisfactorily explains the existing empirical evidence, which indicates a significant amount of unsecured debt by small companies as well as a strong pressure by the financial markets on large companies to use as much unsecured debt as possible. ${ }^{35}$

The second puzzle discussed in Part III is the relative ubiquity of long-term debt. The empirical evidence on that question is mixed. On the one hand, the evidence shows a significant connection between term and collateral: long-term debt is more likely to involve collateral than short-term debt. On the other hand, the pattern is not uniform: significant types of long-term and short-term secured and unsecured debt are easy to find. Prior scholars have provided little or no explanation of either the significant relation between term and collateral or why the pattern suggested by that relation is not ubiquitous. ${ }^{36}$

The last puzzle addressed in Part III is the use of collateral to secure inventory credit. In this context, prior scholars have struggled to explain a phenomenon that does not exist. Contrary to the assumptions that have formed the basis for previous analyses, inventory suppliers often do retain security interests in the products that they sell. Using empirical evidence to glimpse the actual pattern of inventory credit, section III.C suggests factors that might inform an inventory supplier's decision about retaining collateral. ${ }^{37}$

\section{A Decision-Based Model of the Borrowing Decision}

This Article relies on a combination of existing statistical studies and relatively unstructured interviews. Because of the repetitive nature of the interviews, a narrative description of their substance would be neither an appropriate vehicle for explaining the evidence produced by the interviews nor a useful analytical tool for understanding how borrowers and lenders make decisions. I therefore present my findings about these credit decisions within a framework - a model — that

35 See infra section III.A.

36 See infra section III.B.

37 See infra section III.C. 
provides a structure for organizing, understanding, and applying the evidence. This Part of the Article explains that model and the assumptions on which it rests.

The purpose of this project is to analyze the pattern of decisions about secured credit. Hence, the model focuses on the factors that influence borrowing decisions. Specifically, the model approaches the complex of decisions about secured debt from the perspective of a business enterprise that has determined that it wishes to borrow a specified sum of money. ${ }^{38}$ This Article assumes that the borrower will grant collateral to secure the loan only if the borrower believes that the net benefits of the most favorable secured transaction will be greater than or equal to the net benefits of the most favorable unsecured transaction. ${ }^{39}$ References to "net" benefits reflect a subsidiary assumption that the borrower attempts to minimize the costs incurred by both of the parties to the loan transaction. This assumption is designed to ensure that the analysis takes account of two important categories of costs.

First, this Article assumes that the borrower considers factors that increase the expenses of the lender. This assumption relies on the premise that the market for business lending is relatively efficient. In other words, the market allows the lender to include in its charges amounts sufficient to compensate it for the costs that it expects to incur in the transaction, either by assessing separate fees or by altering the nominal interest rate. ${ }^{40}$ The Article assumes that the market

38 This Article focuses on business lending because that is the context in which the secured credit debate has taken place. The Article's methodology also could be applied directly to the consumer context. The principal difficulty would be accounting for the smaller probability that consumer borrowers understand and respond rationally to all of the various costs that they are likely to face over the course of a lending transaction. Cf. Daniel A. Farber, Contract Law and Modern Economic Theory, 78 Nw. U. L. REv. 303, 324 (I983) (summarizing empirical evidence indicating that consumers do not act in accordance with neoclassical assumptions about wealth maximization). See generally Rrchard H. ThaLer, QUASI RATiONAL ECONOMICS (IggI) (collecting empirical studies that document the ways in which individual choices depart from the predictions of utility-maximizing economic theories).

39 The hypothetical assumes that the borrower already has determined that it does not wish to acquire the funds through equity investment. This Article does not undertake to evaluate the considerations that influence the decision to obtain capital through borrowing rather than through equity investment. For an ambitious attempt to integrate the effects of debt and equity on corporate governance, see George G. Triantis \& Ronald J. Daniels, The Role of Debt in Interactive Corporate Governance, 83 CAL. L. REv. IO73 (1995).

40 Lenders certainly attempt to set fees in this way. For example, a lending officer in the metropolitan corporate lending group of a large St. Louis bank explained how he attempted to recover the costs of time spent by the bank's loan audit group in evaluating a potential transaction:

Sometimes we can charge out [our employee's] hours but sometimes the borrower says screw you I'm not going to pay that. So then maybe I say well instead of 200 [basis points] over LIBOR [the London Interbank Offer Rate] it's 225 in the first year, stepping down to 200 - well, I get you coming or I get you going. 
works sufficiently well to induce the borrower and the lender to select the transaction that they believe will have the lowest joint costs. ${ }^{41}$

Second, this Article assumes, at least as a starting point, that the borrower will act with sufficient rationality at the beginning of the lending transaction to consider the indirect costs that it will incur throughout the transaction. "Indirect" costs are costs that the borrower incurs during the transaction that are not included in the interest rate or the fees specified in the loan documents. As discussed below, lending transactions can impose a variety of costs that are not covered by the express payment terms or listed on the closing statement. These costs generally arise from the grant to the lender of the capacity to prevent the borrower from operating its business in the most profitable manner. ${ }^{42}$ Borrowers may not account for those costs perfectly, ${ }^{43}$ but because this Article focuses on the relatively sophisticated parties involved in business lending, the assumption that the borrowers in question at least roughly account for such costs in their borrowing decisions is a reasonable one. ${ }^{44}$

A converse point bears emphasis: this Article assumes that the borrower does not consider costs imposed on entities that do not participate directly in the transaction. Thus, to mention the most important example, the model assumes that the borrower does not consider the costs that the decision to secure a debt may impose on other creditors whose prospects for repayment are harmed more by a secured transaction than by an unsecured transaction, except to the extent that those

Interview with Clyde F. Wendel, Senior Vice President, The Boatmen's National Bank of St. Louis, in St. Louis, Mo. (July 2I, 1995) [hereinafter Wendel Interview] (transcript at 16, on file with the Harvard Law School Library). For an explanation of the reference to "basis points," see note 136 below.

41 This approach is common in the literature (although it often is couched as a statement of fact rather than as an assumption). See, e.g., Jackson \& Kronman, supra note 5, at 1152 ("Both parties will have an incentive to arrange their transaction in a way that minimizes the sum of [all of the costs that the parties incur], since they can share any savings between them.").

42 See infra section II.B.2.

43 See, e.g., Arthur T. Denzau \& Douglass C. North, Shared Mental Models: Ideologies and Institutions, 47 KYKLOS 3, 5-13 (1994) (analyzing reasons why the actual choices of individuals do not reflect the substantive rationality that is the basic assumption of neoclassical economics); see also infra p. 673 (discussing the relative ability of different borrowers to evaluate the costs of loan transactions).

44 The interviews discussed in this Article provide support for that point as well. See, e.g., Telephone Interview with Joseph W. Robertson, Jr., Chief Financial Officer, Weingarten Realty Investors (July II, 1995) [hereinafter Robertson Interview] (transcript at 2, 10, 18, 21, on file with the Harvard Law School Library) (citing loss of flexibility as a reason to avoid issuing secured loans). This Article does not suggest that borrowers always act rationally; it does, however, offer an explanation for why rational, creditworthy borrowers frequently would choose not to secure debts. The possibility remains that borrowers choose not to secure debts for other reasons that are not captured by rational-actor analysis. See, e.g., LoPucki, supra note 8, at I930 (arguing that corporate managers issue unsecured debt for personal reasons inimical to the interests of the borrowing corporation). But see infra p. 67 I (rejecting LoPucki's argument). 
creditors will be able to react to the grant of collateral by imposing higher interest costs on the borrower. ${ }^{45}$ Hence, because this Article does not consider all of the economic costs of the decision to secure a loan, the analysis does not prove that secured lending is (or is not) a good thing for the economy as a whole. ${ }^{46}$ The Article attempts to explain the pattern of secured lending as it actually occurs in the economy, not to evaluate the efficiency or propriety of secured credit in the abstract.

A final point about the model relates to timing. Because this Article aims to explain why borrowers secure their debts, it focuses on the costs that the parties perceive at the time that they enter the transaction, not the costs that the parties actually incur during the course of the disbursement and repayment of funds. Borrowers and lenders cannot negotiate loan terms that impose costs based on the actual losses that will arise during the transaction; they must negotiate loan terms based on estimates of future events (relying, of course, on the costs actually incurred in previous transactions). And because the loan terms on which the parties agree determine the borrower's choice between secured and unsecured debt, the "pre-loan" perception of the costs of nonpayment is the relevant one. ${ }^{47}$

45 Prior scholars have made much of the effect of future borrowing costs on a borrower. See, e.g., LoPucki, supra note 8, at 1896-Ig02. Although a full rebuttal of that position is far beyond the scope of this Article, the effect does not seem to explain much of the pattern of secured credit. This Article's analysis identifies real cost savings from secured credit that go far beyond a simple externalization of risk to future creditors who would charge for the risk if they could. If this cost savings theory is correct, secured credit has the potential to reduce the borrower's overall borrowing costs, not just the costs of the particular transaction in which credit is secured.

Having said that, I acknowledge that secured credit reduces the private costs of borrowing in the frequent situations in which the other creditors have no realistic opportunity to pass those costs on to the borrower (for example, when the other creditor is the victim of a tort committed by the borrower). See Ronald J. Mann, The First Shall Be Last: A Contextual Argument for Abandoning Temporal Rules of Lien Priority, 75 TEx. L. REv. II, 21-23 (1996). Those purely private savings, however, provide no justification for secured credit. Thus, the legal system should act where feasible to reverse that externalization. See id. at 25-3I (arguing that reversal of lien priority in the construction loan context enhances efficiency by preventing externalization of risk to nonadjusting contractors).

46 Tom Jackson and Tony Kronman offer the classic statement of the problem: "At first blush, it may seem unfair that a debtor should be allowed to make a private contract with one creditor that demotes the claims of other creditors from an initial position of parity to one of subordination." Jackson \& Kronman, supra note 5, at Ir47; see also LoPucki, supra note 8, at r899 ("Security is an agreement between $A$ and $B$ that $C$ take nothing."). Because this Article's main objective is empirical, I do not consider the normative question of which rights the law should give to secured creditors. This is not to say that normative argument cannot be supported by empirical analysis. See Mann, supra note 45 , at 44-67 (presenting empirical evidence about the construction industry to support the normative argument that a construction lender should not have priority over contractors that work on a construction project even if the construction lender receives a prior lien on the project).

47 The more common terminology would refer to parties' "ex ante" perception of the costs. See, e.g., Kham \& Nate's Shoes Number 2, Inc. v. First Bank, 908 F.2d I35I, I358 (7th Cir. 


\section{The Benefits and Burdens of Secured Credit}

\section{A. Benefits: Why Would a Borrower Ever Secure Its Debt?}

The first step in analyzing how a borrower decides whether to secure a particular debt is to ask why a borrower ever would secure any of its debt. 48 After all, a borrower receives no direct benefit from an arrangement that enhances a lender's ability to force the borrower to repay a loan. My answer is simple: the advantages that a lender receives from a grant of collateral can lower the lender's anticipated overall costs and thus indirectly lower the costs that the borrower must pay to induce the lender to make the loan. ${ }^{49}$ Although this answer may seem obvious, this Article's willingness to embrace the multiple factors that affect commercial lending decisions and its focus on the mechanisms by which secured credit can facilitate those transactions represent a significant advance over prior work. This Article distinguishes two general groups of advantages for the lender: the lender's direct legal rights to force repayment by taking the collateral, and the less direct advantages that operate before the lender tries to

1990) (opinion of Easterbrook, J.). Reference to the parties' "pre-loan" perception of the costs seems clearer.

48 The concepts of "security" and "collateral" are admittedly arbitrary, and parties surely can obtain many of the benefits associated with secured transactions through arrangements that are not technically "secured." See, e.g., LoPucki, supra note 8, at I92 I-23 (explaining how each of the legal benefits attributable to secured credit can be obtained in unsecured transactions); Scott, supra note 12 , at 912 (criticizing "the implicit assumption that security is a meaningful generic concept"). Notwithstanding the arbitrariness of defining the boundaries of "secured credit," the concept has sufficient content to serve as a tool for inquiry.

To be sure, a complete description of the pattern of secured credit would take into account the availability of alternate transactions that effectively provide the benefits of a secured transaction even though they are technically not secured. See, e.g., Robertson Interview, supra note 44 (transcript at 13-14) (describing the functional similarity between nonrecourse secured financing and asset securitization through special-purpose entities). This omission from my analysis is not, however, a serious problem. At least in the short run, the novelty of unconventional transactions less predictable in effect and more difficult to understand - substantially undermines their general attractiveness to prospective borrowers and lenders.

49 Some scholars have offered explanations of secured credit that do not rest on its ability to lower the costs of the specific loans in which it occurs, but rather on more general effects on the borrower's overall credit structure. The most well delineated of those explanations is Saul Levmore's model, which attributes much of the benefit of secured credit to the posited lower costs of the borrower's unsecured borrowings. Levmore argues that secured credit lowers a borrower's overall borrowing costs through focusing the incentive to monitor a borrower's activities in a sirgle creditor and rewarding that creditor for its monitoring efforts by granting it a priority recovery. See Saul Levmore, Monitors and Freeriders in Commercial and Corporate Settings, 92 YALE L.J. 49, 53-59 (1982). As Paul Shupack has explained, however, "it is not at all obvious how the general [unsecured] creditors are helped by monitors whose advantage lies in the collateral rather than in the debtor." Paul M. Shupack, Defending Purchase Money Security Interests Under Article 9 of the U.C.C. from Professor Buckley, 22 IND. L. REv. 777, 782 n.16 (1989); see Jackson \& Kronman, supra note 5, at Ir54 n.44 (arguing that later creditors will not be able to free ride on policing by earlier creditors); see also Schwartz, The Continuing Puzzle, supra note 9, at I055-59 (criticizing Levmore's argument from a more abstract perspective). 
obtain payment forcibly. The direct legal advantages increase the likelihood that the lender can forcibly collect on default. The indirect advantages not only give the borrower a powerful incentive to repay by enhancing the consequences of nonpayment, but also substantially offset the separation of interests inherent in lending transactions. If the lender understands these effects when it makes the loan, the advantages lower the lender's pre-loan estimate of the likelihood of nonpayment and ultimately lower the anticipated aggregate costs of the transaction. Hence, the advantages of security can lead the lender to ease the terms of the transaction.

I. Direct Advantages: Enforcing Payment. - The most obvious advantage to the lender of issuing secured credit is that receiving collateral increases the likelihood that the lender will be able to collect the loan forcibly if the borrower does not voluntarily repay it.50 As Lynn LoPucki has explained, the law of secured credit (whether Article 9 or the less standardized principles regarding mortgages $)^{51}$ enhances the lender's ability to enforce payment in at least three separate ways: by encumbering collateral (so that the lender has a permanent interest in an identifiable asset or group of assets); by granting priority (so that the lender will be paid before other creditors); and by enhancing the lender's remedy (so that the lender can coerce payment more quickly than it could if its debt were not secured). ${ }^{52}$ If the lender believes when it makes the loan that these advantages increase the likelihood of repayment, the lender can charge less for the loan, thus lowering the aggregate costs of the transaction..$^{53}$

2. Indirect Advantages: Before Collection. - As Bob Scott noted more than a decade ago, the enhancement of the lender's ability to

50 See, e.g., Schwartz, supra note 5 , at 7 (asserting that security benefits borrowers "largely by allowing the secured party to take the property subject to its security interest and sell it to reduce or eliminate the debt").

51 One of the methodological goals of this Article is to start to remedy the separation of scholarship regarding loans secured by personal property (typicaily referred to as secured credit) from scholarship regarding loans secured by real property (typically referred to as mortgages). Lynn LoPucki and Elizabeth Warren recently published a pioneering attempt to integrate the study of the real-property security system with the study of the personal-property security system. See Lynn M. LoPucki \& Elizabeth Warren, Secured Credit: A Systems Approach (I995). For an older effort to integrate analysis of those systems, see GEORGE E. OSBORNE, CASES AND Materials on Property Security (2d ed. r954).

52 See LoPucki, supre note 8, at I92I-23 (stating that the doctrinal concept of security consists of these three attributes).

53 In some cases, the net benefit from enhancing the lender's ability to enforce collection will be offset by an increase in the borrower's costs of borrowing in other transactions. Borrowing costs rise because informed unsecured creditors will charge more for their loans if previous encumbrances make their loans inordinately risky. See, e.g., Jackson \& Kronman, supra note 5, at II53-54; Schwartz, supra note 5, at 7-9. In all likelihood, however, some creditors will not be able to react. See supra note 45 . 
collect the loan forcibly is not the only advantage ${ }^{54}$ - or even, in many cases, the leading advantage ${ }^{55}$ - that motivates parties to secure debt. Subsequent scholars, however, have done little to explain exactly what the indirect advantages of secured lending are and how they work. The evidence presented in this Article suggests that the direct advantages discussed above carry with them a number of practical advantages that have significance before the lender attempts to obtain repayment forcibly through the legal system. ${ }^{56}$ Specifically, the

54 See Scott, supra note 12, at 950. Scott notes:

[T] ]he function of secured credit is conceived within the industry as enabling the creditor to influence debtor actions prior to the onset of business failure. This conception is markedly different in effect from the traditional vision of collateral as a residual asset claim upon default and insolvency. Security is taken for its active rather than its passive properties. Id.; see also Interview with Richmond W. Coburn, Vice President, The Boatmen's National Bank of St. Louis, in St. Louis, Mo. (July 6, I995) [hereinafter Coburn Interview] (transcript at 4 , on file with the Harvard Law School Library) ("[W]e never want to rely upon the liquidation of that asset for repayment . . . .7); Interview with Treasurer of Anonymous Manufacturer (Jan. 9, I996) [hereinafter Manufacturer Treasurer Interview] (transcript at 7, on file with the Harvard Law School Library) ("[T]he lender almost invariably doesn't ever want to become the owner of that asset." $)$.

Scott's point is easy to overstate. There are contexts - such as the heavily asset-based lending that dominates the real-estate lending sector - in which the parties view the ability to enforce collection out of the collateral as the most important reason for taking security. For example, in an interview with the division manager overseeing the real estate group of a $\$ 16$ billion bank holding company, I asked the subject what he personally thought was "the most important benefit that the lender gets out of taking collateral." He stated without hesitation that "a lot of times the bottom line is you've got your money out of the collateral." Interview with Harry C. Mueller, Senior Vice President, Mercantile Bank of St. Louis, N.A., in St. Louis, Mo. (July 1o, 1995) [hereinafter Mueller Interview] (transcript at 2, on file with the Harvard Law School Library). Lenders outside the real estate area made similar comments. See, e.g., Telephone Interview with Gordon S. Massie, Portfolio Manager, American General Corporation (July 14, 1995) [hereinafter Massie Interview] (transcript at 2, on file with the Harvard Law School Library) (stating, based on his experience as the manager of a $\$ 900$ million securities portfolio for a life insurance company, that the ability to obtain payment out of the collateral is the most important benefit of taking collateral).

55 One reason why lenders would be imprudent to rely predominantly on their ability to obtain forcible repayment through liquidation of the collateral is that they are generally unable to recover the indirect costs that they incur when monitoring a problem loan. Lenders also face a strong likelihood that liquidation of the collateral will not even result in full repayment of their principal and interest. A standard lending text for bankers offers a particularly poignant example in its discussion of the difficulties of a Dutch bank that loaned money to a fur company. When the bank attempted to recover its loan out of live beavers that had been pledged as collateral, animal rights activists prevented the slaughter of the beavers. Eventually, the bank paid to have the beavers shipped to Uruguay, where they were released. See George E. Ruth, Commercial. LENDING 250-51 (2d ed. 1990). For an empirical analysis of the problems that lenders face in attempting to recover loans by forcible liquidation, see Ronald J. Mann, Liquidating the Collateral of Distressed Debtors: A Case Study II-I4 (Oct. 28, 1996) (unpublished manuscript, on file with the Harvard Law School Library).

56 The idea that indirect advantages can constrain conduct without recourse to the legal system is neither novel nor unique to the secured credit situation. For the seminal work on this idea, see Stewart Macaulay, Non-Contractual Relations in Business: A Preliminary Study, 28 AM. Soc. REv. 55 (1963). David Charny, Robert Ellickson, and Eric Posner have written the most impor- 
grant of collateral can enhance the lender's ability to limit subsequent borrowings, increase the borrower's incentive to attempt to repay the loan voluntarily, and facilitate restraints on the borrower's incentive to engage in risky conduct. ${ }^{57}$

(a) Limiting Subsequent Borrowings. - Although never identified in prior scholarship, one of the simplest and most significant advantages of secured credit in practice is that it enhances the lender's ability to limit subsequent borrowings..$^{58}$ Lenders in particular circumstances may want to limit subsequent borrowings for various reasons, ${ }^{59}$ but the most general reason is the belief that the borrower will pay more attention to its business if the borrower has a more substan-

tant recent explications of this idea. See David Charny, Nonlegal Sanctions in Commercial Relationships, IO4 HARV. L. REv. 373, 39I-408 (I990) (offering a tripartite typology of nonlegal sanctions and explaining the circumstances in which they are more effective than legal sanctions); Robert C. Ellickson, A Critique of Economic and Sociological Theories of Social Control, I6 J. LEGAL STUD. 67, 7I-90 (I987) (offering a taxonomy of five different types of rules to control behavior and criticizing the "legal-centralist tradition," which ignores the importance of the four types of nonlegal rules); Eric A. Posner, The Regulation of Groups: The Influence of Legal and Nonlegal Sanctions on Collective Action, 63 U. CFI. L. REv. 133, I44-65 (I996) (discussing the relation between the nonlegal sanctions available to private groups and the legal sanctions imposed by the state). This Article is the first sustained attempt to consider the nature of these indirect advantages in the context of secured lending.

57 Randy Picker has offered a somewhat different, although overlapping, articulation of five different roles that security interests can play. See Randal C. Picker, Security Interests, Misbehavior, and Common Pools, 59 U. CHI. L. REv. 645, 650-53 (I992). The principal difference between Picker's discussion and the present analysis is that this Article relies on empirical evidence, focuses on leverage, and emphasizes the mechanisms through which security interests affect transactions. Picker does not present any significant empirical evidence to support his analysis and does not discuss either leverage or the practical mechanisms by which secured credit operates.

58 See, e.g., Frank P. Johnson \& RICHARD D. Johnson, BANK MANAGEMENT I60 (1983) (American Bankers Association textbook) (stating that "[f]or most secured commercial loans, the purpose of collateral is to provide a source of repayment in case of default and to limit the borrower's capacity to borrow from other sources" (emphasis added)); Interview with Joe DeKunder, Vice President, NationsBank of Texas, N.A., in St. Louis, Mo. (June I3, I995) [hereinafter DeKunder Interview] (transcript at 3 , on file with the Harvard Law School Library) ("[W] want to assure ourselves that the [borrower] in a worst-case scenario . . . will not go out and pledge the collateral somewhere else."); see also Interview with Anonymous Office Building Developer (July 13 , I995) [hereinafter Office Building Developer Interview] (transcript at 7-8, on file with the Harvard Law School Library) (stating that his company would find no practical difference between a mortgage and an enforceable agreement barring him from granting a subsequent lien). I am in the midst of an empirical research project about small-business lending, which suggests that the desire to limit future borrowings is particularly important in that context.

59 Bob Scott, for example, believes that lenders want to limit subsequent borrowings only as a way to ensure priority. See Scott, supra note I2, at 945 . Because he does not consider the effects of future debt on the borrower's incentive to attend to its business, he does not see any separate benefit in secured credit's capacity to limit subsequent borrowing. See id. Another rationale was offered by a banker who stated that he likes to prevent subsequent borrowing to avoid the strategic difficulty of having another adverse party to deal with in the event that the borrower becomes distressed. See Mueller Interview, supra note 54 (transcript at 13-14). 
tial stake in the business - more to gain and more to lose. ${ }^{60} \mathrm{By} \mathrm{lim-}$ iting the borrower's ability to obtain large loans in the future, the lender limits the borrower's ability to decrease its interest in the business, as long as the lender also can limit the borrower's ability to sell its ownership interest in the business. ${ }^{61}$

Although the legal rights that constitute a grant of collateral do not directly bar subsequent borrowings, a grant of collateral can limit the borrower's ability to obtain future loans by reducing its ability to grant a valuable security interest to subsequent lenders. ${ }^{62}$ That limita-

60 See, e.g., I Grant S. Nelson \& Dale A. Whitman, Real Estate Finance Law § 5.21, at 297-98 (Practitioner Treatise Series 3d ed. 1994) (explaining that restrictions on subsequent encumbrances are "utilized mainly to protect against impairment of mortgage security by a debtor who incurs a junior mortgage debt and thus reduces his or her economic stake in the mortgaged real estate"); Robertson Interview, supra note 44 (transcript at 22) (statement of Chief Financial Officer of NYSE real estate company) ("LLenders bar subordinate liens b]ecause they want the borrower to have equity in the project. They do not want the borrower gutting [the project] taking all the money out via subordinate loans - so that he cannot walk away."). This idea exemplifies the well-recognized general point that managers of businesses have a greater incentive to operate their businesses profitably when they have more to lose upon failure of the business. This point is distinguishable from the related observation that debt can affect the borrower's appetite for risk. The problem for the lender here is not so much that the leverage caused by debt tends to make the borrower operate the business more riskily, but that the absence of equity tends to lessen the borrower's incentive to attend to the business at all. See Michael C. Jensen \& William H. Meckling, Theory of the Firm: Managerial Behavior, Agency Costs and Ownership Structure, 3 J. FIN. ECON. 305, 3I3 (1976) (distinguishing between enhanced incentive for risktaking and diminished incentive for managerial effort and suggesting that the diminution in effort is the more significant of the two problems).

61 Interviews with lenders suggest that secured lenders are able to bar transfers of the borrower's ownership. See Coburn Interview, supra note 54 (transcript at 19-20) (describing loan restrictions on the sale of equity interest in strip shopping centers given as collateral); DeKunder Interview, supra note 58 (transcript at 22-23) (describing restrictions in secured and unsecured small-business loans on transfer by borrower of an interest in its business); Mueller Interview, supra note 54 (transcript at $\mathrm{I2}$ ) (describing restrictions on change of ownership of borrowers in real-estate loans generally); see also RICHARD BROOK, DEBT CovENANTS AND EVENT RISK: THE Practitioner as a Source of Evidence ig (Center for Law and Econ. Studies, Columbia Univ. Sch. of Law, Working Paper No. 5I, I9go) (reporting that interviews with bond practitioners indicate that covenants in publicly traded unsecured debt frequently prohibit sale-leaseback transactions and mergers).

Many of the documents provided by the interview subjects also support this proposition. See, e.g., NationsBank of Texas, N.A., Deed of Trust, Assignment and Security Agreement \& ig [hereinafter NationsBank Mortgage] (on file with the Harvard Law School Library) (commercial real estate mortgage) (authorizing lender to accelerate the date of maturity if the borrower transfers any part of the collateral or any beneficial interest in the borrowing entity); NationsBank of Texas, N.A., Security Agreement III E.2 \& G.x.d [hereinafter NationsBank Small-Business Security Agreement] (on file with the Harvard Law School Library) (security agreement for small-business loans) (requiring a warranty that the borrower owns the collateral and defining the event of default to include "substantial change in any fact warranted" in the agreement).

62 In most cases, any subsequent security interest would be subordinate to the existing security interest. Thus, the subsequent interest would be considerably less valuable, both because it would be subordinated to the debt secured by the previous security interest and because of the relatively unfavorable strategic position of a subordinate secured creditor. 
tion, in turn, may make future borrowings relatively expensive (and thus less attractive) for the borrower.

Of course, a borrower does not need to grant a lien to promise to refrain from subsequent borrowings; the borrower can make a negative covenant or negative pledge. For several reasons, however, those promises have quite a limited practical effect, especially when the borrower is a small company. The first problem with a negative covenant is that a court is unlikely to treat a debt (or lien) issued in violation of such a covenant as void. ${ }^{63}$ Hence, a subsequent lender that takes such a debt or lien may not be significantly hindered by the violation of the prior covenant, especially if the subsequent lender is not aware of the prior covenant when it makes its loan.

That problem would not be serious if the negative covenant lender could be sure that it quickly would discover covenant violations. If the lender learns of the default quickly enough to force the borrower into bankruptcy within ninety days of the violation of the covenant, the lender may be able to avoid the debt or lien as a preference. ${ }^{64}$ Unfortunately for the negative covenant lender, learning of the default in time to take action is often quite difficult, especially if the borrower is a small company. For many lenders, conducting routine U.C.C. searches of all of the borrowers in their portfolios is too expensive to be a practical option. ${ }^{65}$ Nor is it always practical for lenders to rely on credit services such as Dun \& Bradstreet to learn of covenant violations by their borrowers. Some scholars have assumed that reports available from Dun \& Bradstreet and similar companies provide an inexpensive and effective way for lenders to monitor the activities of their borrowers. ${ }^{66}$ The lenders who addressed this assumption in the interviews for this Article, however, uniformly agreed that these reports cannot protect them against subsequent loans that violate their

63 See, e.g., I Nelson \& WhItMan, supra note 60, $\$ 3.38$, at I20-24 (discussing the limited enforceability of negative pledge covenants in the real estate context); LoPucki, supra note 8 , at 1926 \& n.I5I (discussing problems with the judicial enforcement of negative pledge covenants).

64 See II U.S.C. \$ 547(b) (1994); LoPucki, supra note 8, at 1926-27.

65 See, e.g., Wendel Interview, supra note 40 (transcript at 6) (statement of corporate lending officer for bank) ("WW]e don't normally do a U.C.C. search other than when we are entering into a new relationship ... or when we have a troubled situation ... or if we are in the process of taking collateral."); Telephone Interview with R.O. Wirengard, Director of Credit, Eveready Battery Company, Inc. (July 13, I995) [hereinafter Wirengard Interview] (transcript at 5-6, on file with the Harvard Law School Library) (stating that his company does not routinely do U.C.C. searches).

66 See, e.g., LoPucki, supra note 8, at 1943 \& n.210 (asserting that creditors can "monitor[] the vital signs of the debtor's business from a Dun \& Bradstreet report" and citing other scholars who have made similar assertions); $i d$. at I936 ("[Sophisticated trade creditors] extend short-term credit and monitor U.C.C. filings through credit reports to discover the grant of security when it comes."). 
loan documents, either because the information is not sufficiently accurate or because it is untimely. ${ }^{67}$

These problems are considerably less significant with respect to public companies because of the difficulty that these companies will face if they try to issue debt or liens without the subsequent lender discovering the existence of prohibitive covenants in prior debt instruments. 68 The most obvious reason for this difficulty is the level of examination of the borrower's affairs that is characteristic of the large transactions in which such companies engage. A typical lender receives not only representations and warranties from the borrowing entity, but also assurances from the borrower's counsel that the transaction does not violate the terms of any previous loans to the borrower. 69 A second reason is the need of these companies to return so frequently to the public debt markets. If a large company dependent on the public debt market issues debt in violation of a covenant in a prior loan, public revelation of that violation is likely to seriously disrupt the company's efforts to maintain the credit relationships necessary to operate its business. ${ }^{70}$ Accordingly, these companies can give a commitment to refrain from violating covenants limiting the issuance

67 See Interview with Richard Greco, Regional Manager of Deutsche Financial Services Corporation, in Des Peres, Mo. (July 18, 1995) [hereinafter Greco Interview] (transcript at 16-17, on file with the Harvard Law School Library) (describing the inadequacies of Dun \& Bradstreet reports and focusing on the untimeliness of information and inaccurate reports of U.C.C. filings); Wendel Interview, supra note 40 (transcript at 6) (statement of bank loan officer) (explaining that he does not rely on Dun \& Bradstreet reports to monitor troubled debtors because "I haven't found Dun \& Bradstreet to be a particularly accurate report"); Wirengard Interview, supra note 65 (transcript at 5) (statement of trade creditor) (describing the inadequacies of Dun \& Bradstreet data and focusing on untimeliness and cost of information); see also Telephone Interview with Andrea J. Dunn, Worldwide Credit Manager, Corporate Treasury, Hewlett-Packard Company (Jan. 4, 1996) [hereinafter Dunn Interview] (transcript at 6, on file with the Harvard Law School Library) (stating that monitoring of her customers' credit generally is limited to "periodic review"); Interview with William J. Kimmins, Jr., Treasurer, Anheuser-Busch Companies, Inc., in St. Louis, Mo. (Oct. 26, r995) [hereinafter Kimmins Interview] (transcript at 15, on file with the Harvard Law School Library) (discussing the trade-credit practices of a Fortune 100 manufacturing company, which include a policy of reviewing credit reports only annually).

68 See Wendel Interview, supra note 40 (transcript at 22-23) (statement of bank officer who lends only to large companies) (stating that he doubts that his borrowers could successfully borrow money in the face of a negative pledge covenant).

69 See, e.g., LoPucki, supra note 8, at I926-27.

70 See Telephone Interview with Sonia W. Hamstra, Director, Real Estate Investments, American General Corporation (Aug. 2, I995) [hereinafter Hamstra Interview] (transcript at 5, on file with the Harvard Law School Library) (statement by life insurance company investment officer) (explaining that the credit markets would be likely to react negatively to any action by an issuer of public debt that was inconsistent with the borrower's previous representations about its future financing plans); LoPucki, supra note 8 , at 1927-28 (discussing an interview with a New York attorney who made a similar point). 
of further debt and liens that is more credible than anything that a small company can offer. ${ }^{71}$

In sum, a grant of collateral provides a practical way to enhance the enforceability of covenants against future debt and liens, especially for entities that lend to smaller borrowers for whom there is no practical means of monitoring compliance with such a covenant. When a grant of collateral significantly lowers the likelihood that the borrower will obtain future borrowings, the lien aids the parties by lowering the lender's pre-loan perception of the risk that excessive future borrowing might lead to default.

(b) Enhancing the Borrower's Incentive to Pay. - The second way in which a grant of collateral can provide indirect pre-enforcement advantages is by giving the lender leverage that increases the borrower's incentive to repay the loan. ${ }^{72}$ There is nothing new about the idea that the lender has considerable leverage over the borrower based on the borrower's desire to avoid the loss that it would suffer if the lender exercised its legal remedies. ${ }^{73}$ But no one has identified anything about secured credit in particular that enhances the lender's leverage over the borrower.

71 Existing empirical evidence provides some support for this analysis because it suggests that negative pledge covenants are quite common in publicly traded debt. See, e.g., Lucian Arye Bebchuk \& Jesse M. Fried, The Uneasy Case for the Priority of Secured Claims in Bankruptcy, IO5 YALE L.J. 857, $92 \mathrm{I}-23$ (1996) (citing empirical studies); Broox, supra note 6I, at 19-20 (discussing information gathered from several practitioners). One of my interviews suggested a similar pattern. See Wendel Interview, supra note 40 (transcript at 21 ). Direct restrictions on subsequent debt do appear, however, to be considerably less common in publicly traded debt. See BRook, supra note 61, at 19-20. My interviews also suggest that lenders are becoming increasingly aware of the potential for enhancing the value of such covenants by fine tuning them to particular situations. Specifically, large companies have a growing tendency to grant a limited type of negative pledge that does not bar all future liens, but instead requires the borrower to retain a specified dollar amount (usually in the range of $150 \%$ of the maximum loan amount) of unencumbered assets. See Hamstra Interview, supre note 7o (transcript at 4) (stating that some senior unsecured debt instruments issued by a publicly traded real estate investment trust require the borrower to maintain a base of unencumbered assets equal to "something like I-r/2 to 2 times whatever your unsecured debt is"); Manufacturer Theasurer Interview, supra note 54 (transcript at 5) (describing a negative pledge that allows the borrower to grant subsequent liens as long as a specified amount of assets remains unencumbered); Robertson Interview, supra note 44 (transcript at II) (statement of a borrower) (describing a revolving credit facility that requires the borrower to maintain a pool of unencumbered assets equal to $150 \%$ of the total amount of credit authorized under the facility).

72 Unlike the ability of secured credit to limit subsequent borrowing, the advantage discussed here is closely related to the substance of the legal rights included in a grant of collateral. To use the common metaphor, the parties here are reacting to the "shadow" of the law - the parties' anticipation of what would happen if formal legal proceedings were to occur. The seminal discussion of that phenomenon appears in Robert H. Mnookin \& Lewis Kornhauser, Bargaining in the Shadow of the Law: The Case of Divorce, 88 YALE L.J. 950, 966-77 (1979).

73 See, e.g., LoPucki \& WARREN, supra note 5I, at 43; David Gray Carlson, On the Efficiency of Secured Lending, 80 VA. L. REV. 2I79, 2 I88-89 (I994); Scoth, supra note 12, at 926-27. 
The leverage of the secured creditor depends on the loss that the secured creditor can inflict on the borrower by enforcing its legal remedies against the borrower. This loss is the difference between two amounts: the loss that the debtor suffers when the secured creditor exercises its remedies (the decrease in value of the borrower's enterprise that would result from the repossession and loss of the collateral in a foreclosure), and the offsetting benefit to the debtor (the reduction of the debt that results from the liquidation of the collateral). Under normal circumstances, because there is a large spread between these two figures, foreclosure gives the lender the ability to inflict a considerable loss on the borrower. ${ }^{74}$ The leverage arises from the one-sided nature of the transaction: the borrower "gives" something that is worth more (often considerably more) than what the lender receives. ${ }^{75}$ The borrower's desire to avoid this loss provides an added incentive to repay the loan voluntarily. ${ }^{76}$

74 A spread will exist whenever a borrower lacks a ready source of capital that enables the borrower to place a bid for the asset that equals the value of the asset to the borrower's enterprise. Thus, as Jim Bowers pointed out to me, the lender would not be able to inflict a loss on the borrower if the market for refinancing functioned perfectly and at no cost. Given the liquidity problems associated with defaulting borrowers, however, I assume that borrowers frequently do not have such a source of capital. See Buckley, supra note 12, at 1434 n.78 (noting the "screening costs involved in obtaining new credit in the brief time permitted, particularly after the negative recommendation of the first lender's [action]"). But $c f$. Mann, supra note 55 (manuscript at 7) (presenting empirical evidence suggesting that refinancing frequently is available to troubled borrowers). On the other hand, as Bob Rasmussen pointed out to me in comments on a draft of this Article, the bankruptcy system mitigates some aspects of the leverage by limiting the creditor's ability to take collateral that has a fair-market value in excess of the debt. See II U.S.C. $\$ 363$ (d) (1994) (barring relief from the automatic stay in most cases in which the debtor has equity in the collateral, as long as the creditor's interest in the collateral is adequately protected); see also Schwartz, Theory, supra note 9, at 243-44 (arguing that the availability of bankruptcy limits secured creditors' procedural advantages over unsecured creditors).

75 The locus classicus for discussion of that phenomenon is a 1983 article by Oliver E. Williamson. See Oliver E. Williamson, Credible Commitments: Using Hostages to Support Exchange, 73 AM. ECON. REV. 519, 537 (1983) (explaining how "hostages" can overcome problems in bilateral contracting); see also Triantis, supra note $\mathrm{II}$, at 246-47 (applying that analysis in the context of secured credit). For a horrific example (which may seem all too realistic to attorneys who customarily represent borrowers), consider a security interest entitling the creditor to take a pound of flesh upon default. Cf. Winliam Shakespeare, The Merchant of Venice, in The Complete Works, act I, sc. 3, ll. I39-66 (Stanley Wells \& Gary Taylor eds., compact ed., Oxford Univ. Press r988) (involving not a security interest, but rather a penalty for failure to perform under a bond). Perhaps a security interest would not have been subject to the difficulties about judicial enforcement that undermined the deterrent effect of the bond. See id. act 4, sc. I.

76 See Elizabeth Warren \& Jay Lawrence Westbrook, The Law of Debtors and Creditors: TeXt, CASES, AND Problems 4-6 (3d ed. 1996). As a number of borrowers explained, the lender does not always have this leverage. Sometimes the lender will not be able to liquidate the collateral for a value equal to the discounted cash flow, which is the amount that the lender would receive if it left the property in the control of the borrower. In those circumstances, the lender's practical control over the borrower can become relatively weak. See, e.g., Office Building Developer Interview, supra note 58 (transcript at 9) (explaining that some cases of default by his company "had been a strategic course of action to reach a default in an effort to 
To put the point more concretely, consider a borrower that secures a loan of $\$$ I20,000 with a lien on a drill press in the borrower's factory. ${ }^{77}$ Assume that the drill press has a current fair-market value of $\$ \mathrm{r} 20,000$, that liquidation pursuant to the security agreement would bring a net recovery of only $\$ 100,000,{ }^{78}$ and that loss of the drill press would diminish the value of the borrower's business by $\$ 400,000 .{ }^{79} \mathrm{In}$ that case, the borrower would suffer a loss of $\$ 300,000$ upon foreclosure and sale of the drill press. ${ }^{80}$ The lender's ability to inflict this loss substantially raises the stakes of default for the borrower: the loss is not just the "ordinary" loss from liquidating an asset at a distressed sale rather than for fair-market value, but also the loss of all of the idiosyncratic and synergistic values that the asset has for the borrower. ${ }^{81}$

The borrower's voluntary decision to repay the loan protects the lender from the vagaries of the liquidation process, and saves the lender the time and hassle (both of which are ultimately reducible to money) of pursuing the borrower and the collateral. As the prospect of that leverage increases the lender's pre-loan perception of the likeli-

renegotiate terms"); Pharmaceutical Company Interview, supra note 20 (transcript at 4) (describing a situation in which a bank lender had little or no leverage because the bank could not lawfully sell the FDA-regulated collateral pledged by the borrower); see also LOPUCKI \& WARREN, supra note 5I, at 43 ("The debtor who can credibly threaten to retain possession of the collateral for a long time, to run up the cost of repossession, or to reduce the value of the collateral before the creditor can gain possession, may be able to take advantage of the creditor in post-default negotiations.").

77 The hypothetical assumes that the value of the collateral has declined since the loan was made, because an equipment loan ordinarily would not exceed $80 \%$ of the liquidation value. See, e.g., DeKunder Interview, supra note 58 (transcript at 29) (describing a bank's policy to limit loans secured by equipment to $80 \%$ of the value of new equipment and $70 \%$ of the value of used equipment).

78 Given the significant inefficiencies of the forced sale procedure for liquidation of collateral, the hypothetical's assumption that the liquidation value would be more than $80 \%$ of the fairmarket value may even be optimistic.

79 Many factors could cause a borrower to value an asset more highly than the market. For example, the borrower may have made tangible asset-specific investments that would be wasted if the asset is lost. In the hypothetical, the borrower might lose not only the value of the drill press standing alone, but also much of the value of the factory and business that uses the drill press, as well as the costs of training the employees who operate it. Additionally, the borrower may have an idiosyncratic or emotional investment in the asset; perhaps the loss of the asset would cause the borrower to lose a family business. See generally Robert Nozick, The Nature of RationALITY 2I-35 (1993) (discussing how individual attention to sunk costs and symbolic utility can cause individuals to receive benefits not reflected in market values).

80 The borrower loses an asset that it values at $\$ 400,000$ and receives a $\$ 100,000$ credit on its outstanding loan, for a net loss of $\$ 300,000$.

81 See LoPUCKI \& WARREN, supra note 5I, at 43 (explaining that a creditor that can take possession of collateral immediately "can terminate the debtor's business"). 
hood of repayment, the lender should be willing to make the loan at a lower cost to the borrower. ${ }^{82}$

Of course, secured lenders are not alone in having leverage over borrowers. For example, a lender that advances a line of credit that it can call on demand has a significant amount of leverage based on its ability to bring the borrower's business to an immediate standstill. But the legal advantages that accompany a grant of collateral enhance a particular and important type of leverage: the ability to inflict loss through liquidation of the borrower's assets. ${ }^{83}$ To be sure, an unsecured lender can inflict a similar loss by instituting a lawsuit, obtaining a judgment, and executing on a judgment lien. But the process for collecting unsecured debts tends to be much more protracted than the process for proceeding against collateral, especially when the borrower actively opposes the lender's efforts to collect the unsecured loan. ${ }^{84}$ This protracted process often significantly reduces the practical ability of the lender to inflict losses by liquidating the borrower's assets because the delay gives the borrower a greater period of time to raise funds to pay off the loan or to protect itself in other ways (such as by bidding at the sale of the collateral).85 Given the general lack of liquidity experienced by borrowers that are having trouble making payments on their debts, ${ }^{86}$ the additional time that a borrower can withstand an unsecured creditor's collection efforts should significantly enhance the borrower's ability to protect itself. ${ }^{87}$

82 As I discuss below, leverage has a negative side as well, which I believe to be one of the most costly aspects of secured credit. See infra section II.B.2. This discussion of voluntary repayment, however, is designed to show only the circumstances in which leverage is positive; generalizations about the relative prevalence of the positive and negative aspects of leverage are not required (or, I think, possible).

83 Unlike line-of-credit leverage, liquidation leverage is available even in long-term loans. Because the line-of-credit leverage discussed in the text arises out of the ability of the lender to terminate the relationship at will, that leverage should not be an important factor in the parties' efforts to structure a long-term lending relationship.

84 For an entertaining look at the difficulties an unsecured creditor faces in collecting even after it obtains a judgment, see LOPUCKI \& WARREN, cited above in note 5I, at 3-20.

85 Another strategy that has developed as a way for borrowers to prevent unsecured lenders from expeditiously taking control of borrowers' assets is for the distressed borrower to grant a "blocking" security interest to a friendly coalition of unsecured creditors after the default arises but before the hostile unsecured creditor obtains a lien on the borrower's assets. See LoPucki, supra note 33 , at $1539-44$.

86 For a discussion of the illiquidity of troubled borrowers, see note 74 above.

87 See Triantis, supra note II, at 246; cf. Interview with Anonymous Mall Developer, in St. Louis, Mo. (June 20, I995) [hereinafter Mall Developer Interview] (transcript at 4, on file with the Harvard Law School Library) (explaining that a regional shopping mall developer's willingness to grant a substantial lien would enhance the ability of the lender to take the collateral during a temporary disturbance of cash flow). But see Adler, supra note 7, at 86 ("II]t is unclear why secured creditors innately have a significantly greater opportunity to misbehave than do unsecured creditors."). 
This situation often makes the unsecured creditor's leverage considerably less than the secured creditor's. 88

(c) Mitigating Incentive Problems. - The third practical advantage associated with a grant of collateral is the enhancement of the lender's ability to restrain the borrower from engaging in risky conduct that (in the lender's view) decreases the borrower's ability to repay the loan. A commercial lending transaction differentiates the interests of the borrower from the interests of the lender, typically by giving the borrower most of the upside potential and by leaving the lender with much of the downside potential. For example, if the business makes extraordinary profits, the lender's return on its investment generally does not increase; if the business fails, the lender's likelihood of loss increases substantially even though the borrower may lose very little, especially when the borrower's equity investment is limited. Absent some corrective action, that differentiation of interests leads to a differentiation of consequences ${ }^{89}$ that can undermine the likelihood of repayment. A borrower may have a higher preference for risk-taking in such a situation than it would have if it bore all of the risks of failure itself, and thus might be less likely to generate the funds needed for repayment than it would be in the absence of the incentivealtering effects of the loan transaction. 90

88 As Lynn LoPucki and Jay Westbrook have pointed out to me, the leverage of unsecured lenders could be similar to that of secured creditors when unsecured lenders deal with public borrowers that must return to the credit market frequently. See Triantis \& Daniels, supra note 39 , at 1084-85 (explaining that a lender can influence corporate governance because its decision to "exit" can "precipitate the firm's collapse").

89 This Article consistently refers to differentiation of incentives and to the costs of incentives. I eschew the customary reference to "agency costs" because commentators have applied that term so broadly that it lacks significant explanatory power in any specific context. See Carlson, supra note 73 , at 2186 n.I8. Jensen and Meckling developed the "agency cost" terminology to describe the costs that owners of firms incur when the incentives of the managers (the agents) differ from the incentives of the owners (the principals). See Jensen \& Meckling, supra note 60, at 308-10. In the context of this Article, use of the term is misleading because it implies that the borrower is in some sense an "agent" for the lender, an implication that leads many scholars to characterize conduct by a borrower that maximizes the borrower's wealth as "misbehavior" whenever it does not perfectly further the interests of the lender. See Bebchuk \& Fried, supra note 7I, at 873-75; Buckley, supra note I2, at I439-40; Jackson \& Kronman, supra note 5, at II50; Levmore, supra note 49, at 50; Picker, supra note 57, at 646; George G. Triantis, A Free-Cash-Flow Theory of Secured Debt and Creditor Priorities, 80 VA. L. Rev. 2155, 2156-57 (1994). But cf. Jensen \& Meckling, supra note 6o, at 333-37 (discussing the "agency costs of debt" without pejorative references to a borrower's pursuit of its incentives). The characterization of the borrower's conduct as "misbehavior" is erroneous because it ignores the fact that the borrower is just as independent an economic actor, and therefore just as entitled to pursue its own interests, as the lender. As I explain in more detail below, the lender's incentives differ from the ideal incentives just as much as the borrower's incentives do. See infra p. 664. Hence, because neither of the parties has an incentive in all circumstances to maximize the value of the assets, there is no value-neutral basis for deciding that one party's pursuit of its incentives should be viewed as misconduct.

90 For general discussions of the unduly risky preferences of borrowers, see EUGENE F. FAMA \& Merton H. Miller, The Theory of Finance I78-8I (I972); Lynn M. LoPucki \& William 
If the differentiation of incentives diminishes the likelihood that the borrower will repay the loan, it increases the costs of the transaction. Hence, mechanisms that mitigate the differentiation of incentives can decrease the costs of the transaction by lowering the lender's pre-loan assessment of the risk of nonpayment. Relying on existing empirical studies as well as the interviews undertaken for this Article, this section of the Article identifies and explains three different mechanisms through which secured credit lowers the costs associated with the differentiation of incentives: ${ }^{91}$ focusing the lender's oversight on a particular asset, increasing the net value of covenants that constrain the borrower's behavior, and increasing the practical leverage that the lender can use to constrain the borrower's behavior. The section concludes by examining and rejecting a fourth possible mechanism for the correction of incentives: fostering exclusive lending relationships.

(i) Focusing the Lender's Monitoring. - The simplest way in which a grant of collateral increases the effectiveness of the lender's efforts to limit risky behavior is by narrowing the focus of the lender's monitoring. ${ }^{92}$ When the lender has an effective lien on a particular asset, such as a single office building, it can focus its monitoring on that asset (and ignore other assets), secure in the knowledge that repayment is likely as long as the liquidation value of the asset remains greater than the outstanding amount of the loan. ${ }^{93}$ When the lender can limit its attention to a particular asset, rather than scrutinizing the entire company, monitoring should become less expensive. ${ }^{94}$ Further-

C. Whitford, Compensating Unsecured Creditors for Extraordinary Bankruptcy Reorganization Risks, 72 WASH. U. L.Q. II33, Ir34-36 (I994); and Thiantis, cited above in note II, at 234-38. This Article's discussion of the detrimental effects on incentives that arise from a division of the interests in a particular asset draws heavily on Yoram Barzel's transaction-costs model of property rights. See Yoram Barzel, Economic ANAlysis of Property Rights I-I2 (1989).

91 George Triantis also has argued that secured credit provides benefits by mitigating incentive problems. See Triantis, supra note 89 , at 2158-65; Triantis, supra note II, at 234-49. Although useful, Triantis's discussions are relatively abstract and devote little attention to the practical mechanisms through which secured credit can provide those benefits. More fundamentally, his analysis fails to put the benefits in the context of all of the other effects of secured credit that motivate borrowing decisions. See supra note 34 and accompanying text (criticizing unified theories of secured credit).

92 Jackson and Kronman present a contrary argument that secured credit is issued to creditors for whom monitoring is particularly expensive because security renders monitoring less crucial. See Jackson \& Kronman, supra note 5, at I159-61. As other scholars have pointed out, this argument is difficult to reconcile with the observed fact that many of the creditors that are most likely to be adept at monitoring (such as banks) frequently retain security interests. See, e.g., Schwartz, supra note 5, at II n.28; Scott, supro note I2, at 909-Io.

93 For a discussion of the imprudence of a lender's reliance on liquidation value, see note 55 above.

94 See Coburn Interview, supra note 54 (transcript at 4) ("[Y]ou get annual financial statements and various kinds of disclosures, but it's harder to track [the borrower's general financial condition. It's] much easier to track that piece of collateral that you have, be it a shopping center or building or whatever it is."). 
more, by allowing the lender to limit its monitoring to certain types of assets, secured credit makes it easier for the lender to routinize the monitoring, which can lower the costs of monitoring by decreasing the expertise necessary to perform it. 95

(ii) Enhancing the Effectiveness of Loan Covenants. - The most obvious way in which lenders try to solve incentive problems is by including provisions in the loan documents that allow the lender to monitor and oversee the borrower's activities. ${ }^{96}$ For example, sophisticated loan documents commonly include provisions requiring the borrower to provide regular information reports, allowing the lender to conduct inspections, and prohibiting (or placing conditions on) certain types of transactions. ${ }^{97}$ Those provisions enhance the lender's capacity to induce the borrower to conduct its affairs in accordance with the lender's risk-averse interests rather than the borrower's risk-preferent interests. If secured credit can increase the net value of the provisions, then it lowers the aggregate cost of the lending transaction. ${ }^{98}$

Although the empirical evidence available at this time is limited, I believe that secured credit enhances the effectiveness of loan covenants in solving incentive problems. Because secured lenders can focus on particular assets, it is cost-effective for borrowers to allow those lenders to impose stringent, specific covenants that are effective in protecting the particular assets on which the lender has a lien. The lack of focus of unsecured lenders makes it impractical for them to insist on similarly stringent covenants. Loan covenants in the unsecured context focus on global concerns related to company-wide indicators of financial strength, such as maintenance of the borrower's existence, provision of information, compliance with minimum standards of broad financial indicators of income and net worth, and limitations on the issuance of future debt or liens. ${ }^{99}$ Occasionally, although only

95 I owe this point to Jay Westbrook.

96 Empirical evidence suggesting that loan covenants are stricter in debt issued by more highly leveraged firms demonstrates the close relation between loan covenants and the perceived level of the risk that the borrower's incentives will lead it to pursue investment preferences that differ from the lender's incentives. See Mark Carey, Stephen Prowse, John Rea \& Gregory Udell, The Economics of Private Placements: A New Look, Fin. MARkeTs, INSTITUTIONS \& INSTRUMENTS, Aug. I993, at I, 28; Marcel Kahan, The Qualified Case Against Mandatory Terms in Bonds, 89 NW. U. L. REV. 565, 593 (I995).

97 See, e.g., Marcel Kahan \& Bruce Tuckman, Pruate vs. Public Lending: Evidence From Covenants 6-I5 (Harvard Law Sch. Program in Law and Econs. Discussion Paper No. I5 I, I995) (providing an empirical study of the prevalence of various types of covenants in unsecured debt of publicly traded companies).

98 I refer to "net value" because debt covenants lower the aggregate costs of a transaction only if the value that the covenants provide the lender - limiting losses from the differentiation of incentives - exceeds the costs that they impose on the parties in aggregate. As I discuss below, the costs of these provisions are significant, but not likely to exceed the benefits that they provide. See infra pp. 654-55.

99 See KaHAN \& TUCKMAN, supra note 97 , at 6-15. 
rarely in the case of publicly issued debt, the documents in an unsecured transaction also include provisions barring substantial changes in the business or mandating that the borrower maintain its property in good repair. ${ }^{100}$ These types of covenants can do much to prevent some of the most flagrant forms of risky behavior, such as inordinate distributions to shareholders and the issuance of excessive subsequent debt. ${ }^{101}$ Because the covenants operate at a business-wide level, however, they do not prevent the borrower from engaging in several other types of risky activity that can reduce a lender's chances of repayment. ${ }^{102}$ For example, covenants do little to overcome the borrower's natural inclination to engage in risky investment activity, ${ }^{103}$ because specific investment decisions frequently do not have the type of immediate business-wide impact covered by the typical covenants in the unsecured credit context. ${ }^{104}$ Similarly, typical unsecured debt covenants do nothing to prevent the borrower from forgoing valuable investment opportunities that may be necessary to maintain the long-term profitability of the business. ${ }^{105}$

The covenants that tend to be included in secured transactions can be much more effective in limiting the borrower's tendency toward risky behavior. The most basic provision is a prohibition on a sale of the collateral without the lender's consent. ${ }^{106}$ Similarly, a lender fre-

100 See id. at $15-17$.

101 See, e.g., Scott, supra note I2, at 919-20; Triantis, supra note $\mathrm{II}$, at 235-36.

102 For instance, an investment officer for a major life insurance company characterized the covenants in publicly traded debt of real estate investment trusts as "in essence very lax." Hamstra Interview, supra note 70 (transcript at 4). She explained that the covenants are "not intended to be restrictive" of daily operations, but merely to describe "real outside limits beyond which an investor would be really uncomfortable." Id. (transcript at 5); see also Telephone Interview with David R. Edlund, Corporate Finance and Debt Manager, Corporate Treasury, Hewlett-Packard Company (Aug. 21, 1995) [hereinafter Edlund Interview] (transcript at 6, on file with the Harvard Law School Library) ("Because we don't have that much borrowing relative to the size of the corporation the covenants [in our loan documents] are fairly minimal. They're really not very significant.").

103 For description and analysis of that inclination, see Scott, cited above in note 12, at 919, and Triantis, cited above in note II, at 237-38.

104 Consider, for example, a borrower deciding which of two shopping centers to purchase. Each has the same price and the same expected rate of return (15\% per annum). If one has a higher variance than the other ( $20 \%$ chance of a $5 \%$ loss, $80 \%$ chance of a $20 \%$ return for shopping center \#1; $40 \%$ chance of a $12 \%$ return, $60 \%$ chance of a I7\% return for shopping center $\# 2$ ), a highly leveraged borrower might prefer the shopping center with the higher variance (shopping center \#I). The typical covenants would do nothing to constrain the borrower's choice.

105 See Scott, supra note 12, at 923 ("Negative covenants are not effective in controlling the conflicts over growth opportunities. The underinvestment problem does not involve a prohibited action but rather the failure to take an action."); Triantis, supre note II, at 240 ("[F]orcing [managers] to invest in all profitable opportunities is impossible.").

106 See, e.g., NationsBank Mortgage, supra note 6I, \& I9 (authorizing the lender to demand immediate payment of indebtedness if the borrower sells all or any part of the collateral without the lender's written consent); NationsBank Small-Business Security Agreement, supra note 6r, $\S \mathbf{E}\left(\mathrm{I}_{3}\right)$ (prohibiting sale of collateral other than inventory without the written consent of the 
quently will prohibit the borrower from going forward with leases and other significant business decisions about the collateral without first obtaining the lender's consent. ${ }^{107}$ Another set of provisions common in secured lending requires the borrower to maintain the collateral in good condition and specifies actions that the borrower must perform, such as the maintenance of insurance and the payment of taxes. ${ }^{108}$ In the aggregate, these provisions limit the most common ways in which borrowers' incentives might encourage conduct adverse to the interests of lenders.

At least in theory, a lender could include provisions in unsecured debt agreements that prevent the borrower from selling its assets or making any major decisions about operations without the lender's consent. And if lenders could employ those provisions just as easily in unsecured documentation as in secured documentation, then the grant. of collateral would not be the cause of the provisions' effectiveness. The provisions' prevalence in secured transactions and general absence from unsecured transactions, ${ }^{109}$ however, is convincing evidence that secured credit makes the provisions substantially more effective. ${ }^{110}$

lender). If the loan is secured by a floating collateral base (such as financing of accounts receivable or inventory), the lender will not be able to control the disposition of the collateral because it is the nature of the business for the collateral to come and go. In that situation, this particular benefit of secured credit would be diminished considerably.

107 See, e.g., NationsBank Small-Business Security Agreement, supra note 6I, § E(13). Several scholars have suggested that the security interest itself protects lenders against asset substitution. See, e.g., Adler, supra note 7, at 78-79; John D. Leeth \& Jonathan A. Scott, The Incidence of Secured Debt: Evidence from the Small Business Community, 24 J. Fin. \& QuANTITATIVE ANALysis 379, 380-8I (I989); Clifford W. Smith, Jr. \& Jerold B. Warner, Bankruptcy, Secured Debt, and Optimal Capital Structure: Comment, 34 J. FIN. 247, 250 (I979). Without the covenants, however, the security interest would do little or nothing to protect the lender from the borrower's risk-preferent incentives.

108 See, e.g., NationsBank Mortgage, supra note 6r, $\$ \$ 5-6$ (requiring the borrower in a commercial real estate mortgage to pay all applicable taxes and maintain insurance as required by the lender); NationsBank Small-Business Security Agreement, supra note 6r, § E(2), (3) (requiring the borrower in a small-business security agreement to maintain insurance on collateral and to protect collateral from tax liens).

109 My empirical research suggests that asset-specific provisions are not common in unsecured loan transactions. See Hamstra Interview, supra note 7o (transcript at 5) (statement of life insurance company investment officer) (asserting that unsecured debt agreements of publicly traded real estate investment trusts do not include covenants relating to specific assets); Manufacturer Treasurer Interview, supra note 54 (transcript at 5) (describing covenants in standard commercialpaper documentation and in long-term unsecured offering as insignificant to the operation of the company); Massie Interview, supra note 54 (transcript at 7) (statement of manager of securities portfolio for life insurance company) (stating that there are no asset-specific covenants in the typical unsecured debt issues that he purchases); Mueller Interview, supra note 54 (transcript at I3, I9-20) (explaining that unsecured loan transactions by his bank typically do not restrict treatment of particular assets). Standard industry forms support the same conclusion. See, e.g., AMERican bar Found., Corporate Debt financing Project, Commentaries on Model DEBENTURE INDENTURE PROVISIONS art. IO (r97 $\mathrm{r}$ ).

110 Bob Rasmussen offered me an alternate explanation, proposing that a characteristic of borrowers that encourages creditors to require a security interest (such as the perceived riskiness of 
The reason for the relationship is easy to see. In the secured context, the priority rights associated with collateral preserve for the secured lender the benefits that arise out of constraints on the borrower's use of the collateral. In the unsecured context, such constraints only increase the likelihood of repayment to the extent that they actually improve the overall stability of the company. Because this larger goal is much more difficult, such constraints tend to be fairly ineffective: the cost of enforcement frequently would exceed any benefits to the lender.

Even if covenants sometimes can enhance the lender's ability to constrain the borrower from unduly risky activity, the costs of this constraint are significant. ${ }^{111}$ First, the administration of the covenants requires the expenditure of a significant amount of time and money by borrowers, who must seek approval from lenders for transactions covered by the documents, and by lenders, who must evaluate the requests. ${ }^{112}$ Second, and perhaps more important, these provisions subject aspects of the borrower's business to the direction of a party whose incentives differ substantially from the borrower's. The lender's goal in evaluating proposals is to maximize the likelihood of repayment, not to maximize the value of the borrower's equity, or even to maximize the total value of the enterprise. When lenders hin-

the borrower) increases the perceived benefits of the covenants, which in turn leads to their prevalence in secured transactions. See supra note 96 (presenting evidence that riskier borrowers endure stricter covenants). I find Rasmussen's suggestion intriguing; indeed, it may be part of the answer. I doubt that it is a complete answer, however, because my evidence suggests that assetspecific covenants appear even in secured loans to relatively creditworthy borrowers. See, e.g., Robertson Interview, supra note 44 (transcript at ro) (discussing asset-specific covenants in loans to a highly rated public borrower). Furthermore, my hypothesis better explains the particular way in which covenants in secured agreements differ from covenants in unsecured agreements. My evidence does not suggest that the covenants in secured transactions are more stringent in the abstract; it suggests that they are more stringent in their focus on specific assets.

111 Lenders take account of the costs of covenants in structuring transactions. See, e.g., JoHNSON \& Joknson, supra note 58, at I6I (American Bankers Association textbook) (stating that "[t]he added protection [from taking a security interest] must be balanced against the costs associated with perfecting the lien and monitoring and controlling the assets").

112 See, e.g., Telephone Interview with Carl Evans, Chief Executive Officer, Texas Pneumatic Tools, Inc. (July 5, 1995) [hereinafter Evans Interview] (transcript at 12, 17, 21-22, on file with the Harvard Law School Library) (explaining that he recently switched the principal lending relationship of the Texas-based industrial tool company because of unwillingness to adhere to loan covenants sought by the existing lender); Telephone Interview with Jocelyn Sears, American General Realty Advisers, Inc. (July 3I, 1995) (transcript at 3, on file with the Harvard Law School Library) (statement of director of department responding to borrower requests for consents) (estimating that, on a portfolio of 1300 commercial real estate loans, a particular lender receives 200 requests each year for consents to easements, leases, subordinate liens, and similar matters). The president of a developer specializing in community shopping centers anchored by grocery stores stated: "I'm probably supposed to go to them [on major new leases] but typically, forget about it. You just go and do it. Now is that a default?" Interview with Anonymous Shopping Center Developer (July II, I995) [hereinafter Shopping Center Developer Interview] (transcript at 14, on file with the Harvard Law School Law Library). 
der value-increasing business decisions, they impose costs that offset the benefits of a lender's ability to prevent value-decreasing business decisions. The available evidence suggests that those costs are considerable. ${ }^{113}$ Because asset-specific covenants persist in secured lending, even in loans to relatively creditworthy and sophisticated borrowers, it is difficult to believe that they are not cost-effective. ${ }^{114}$ The point is simply that the offsetting costs make the net benefits much less substantial than the scholarly literature on monitoring suggests.

(iii) Effects of Leverage. - The third way in which security can prevent the borrower from engaging in unduly risky behavior is a byproduct of the leverage discussed above. ${ }^{115}$ The lender's ability to inflict severe losses on the borrower through the exercise of the lender's rights in the borrower's collateral enhances the borrower's incentive to refrain from conduct that the lender views as unduly risky and to operate its business in accordance with the lender's desires. ${ }^{116}$ The leverage does more than encourage the borrower to comply with the restrictions that the parties have negotiated and memorialized in the applicable documentation. A prudent borrower would be wary of taking technically permissible actions that the borrower thinks might trouble the lender sufficiently to increase the likelihood that the lender will seize upon a minor default to justify calling the loan. ${ }^{117}$ The ability of security to give the lender expansive influence over the bor-

113 Companies quite commonly make significant payments to bondholders to induce them to release loan covenants in previously issued debt agreements. This practice suggests that those covenants frequently impair profitable transactions. See Marcel Kahan \& Bruce Tuckman, Do Bondholders Lose from Junk Bond Covenant Changes?, 66 J. Bus. 499, 502-04 (1993) (presenting an empirical study of transactions in which debtors have paid their bondholders to release covenants); see also supra note II2 (presenting analogous anecdotal evidence).

114 This belief is buttressed by the statement of a bank division manager that competition makes it difficult to insist on firm loan covenants without jeopardizing the deal. See Mueller Interview, supra note 54 (transcript at 18-19). He explained that his institution experienced considerable losses on real estate loans during the last recession and said that he believes that strict loan covenants substantially improve the likelihood of repayment. Accordingly, his institution is willing to lose business rather than weaken its loan covenants. See id.; see also RICHARD S. Wilson \& Frank J. FabozzI, The NeW Corporate Bono Market 25-27 (rggo) (describing how Moody's takes account of bond covenants in determining what rating it will give to proposed debt issues); Mai E. Iskandar-Datta \& Douglas R. Emery, An Empirical Investigation of the Role of Indenture Provisions in Determining Bond Ratings, 18 J. BANKING \& FIN. 93, I09 (1994) (reporting an empirical study of rated bond issues that concluded that "indenture provisions significantly affect the rating of a new debt issue").

115 See supra pp. 645-49.

116 See, e.g., DeKunder Interview, supra note 58 (transcript at 3) ("[W]hen you're looking at collateral, you're looking at ... the fact that ... you're going to ... try to control the situation if the borrower gets into trouble.").

117 See David Gray Carlson, Debt Collection as Rent Seeking, 79 MiNN. L. REv. 817, 825-26 (1995) (describing how secured credit can "reduce the debtor into a state of servility"); Scoth, supra note 12 , at 945 ("Creditors believe that security is useful in causing the borrower to weigh carefully the consequences of . . . wrongful or careless business actions."); Office Building Developer Interview, supra note 58 (transcript at $\mathrm{r} 2$ ) (describing lenders' practice of using technical defaults 
rower's daily decisionmaking - even in circumstances not foreseen at the time the loan was made - can go far toward diminishing the incentive differentiation created by the underlying loan transaction.

(iv) Fostering Exclusive Lending Relationships. - I close this section by considering the possibility that secured credit fosters exclusive lending relationships that solve the incentive problems entirely, a thesis articulated by Bob Scott in one of the most prominent and wellreceived articles in the field. ${ }^{118}$ The main thrust of Scott's argument is that the use of an exclusive secured lending arrangement will cause "each party [to] . . . act as if it owned all of the property rights in the prospect."119 The argument has a strong commonsense appeal: it seems obvious that a borrower or a lender will think twice about acting contrary to the interests of another party when the other party has the ability to retaliate in future transactions as well as in the transaction at hand. ${ }^{120}$

Several problems, however, undermine Scott's thesis. First, although Scott explains that exclusive relationships give each party an incentive to refrain from upsetting the other, he does not show why the parties' incentives would become exactly the same. Even in a long-term, exclusive lending relationship, the lender's interests - in most or all of its projects with the borrower - will favor an approach considerably more cautious than the approach dictated by the interests of the borrower.121 Second, I see no reason for the benefits of relational lending to be limited to secured lenders; unsecured lenders are just as capable as secured lenders of building relationships with their borrowers. ${ }^{122}$

in an effort to cause borrowers to "volunteer something" that the borrowers are not obligated to do under the applicable documents).

118 See Scott, supra note I2, at 916-Ig.

119 Id. at 918 ; see id. at 916-I9, 936-37 (arguing that optimal development under secured financing requires an exclusive relationship between the borrower and the lender).

120 See, e.g., G. Richard Shell, Opportunism and Trust in the Negotiation of Commercial Contracts: Toward a New Cause of Action, 44 VAND. L. REv. 22 I, 267-69 (I99I) (explaining how the "reputation effect" enhances the stability of long-term commercial relationships); see also Arnoud W.A. Boot \& Anjan V. Thakor, Moral Hazard and Secured Lending in an Infinitely Repeated Credit Market Game, 35 INT'L ECON. REv. 899, 904-I4 (1994) (showing through a formal model how reputational lending can limit the borrower's ability to externalize risk by smoothing out profits and losses).

121 See supra p. 649.

122 One banker who specializes in unsecured loans explained: "[W] hat I'm always trying to do is build partnerships with my customers so anything he wants to do financially he ought to come to his banker first." Wendel Interview, supra note 40 (transcript at 22). Indeed, if anything, the existing empirical evidence suggests a relationship directly opposite to the relationship that Scott posits: a significant inverse correlation between lengthy relationships and collateral. See Allen N. Berger \& Gregory F. Udell, Relationship Lending and Lines of Credit in Small Firm Finance, 68 J. Bus. 35I, 372-77 (1995). 
Finally, and most importantly, the facts appear to be inconsistent with Scott's premise. The existing empirical evidence strongly indicates that exclusive lending relationships are much less common than Scott's analysis suggests. For example, a study of several thousand small businesses that examined only lending from banks (thus omitting several possible types of secured lenders) found that a mere twenty-six percent of borrowers with multiple secured loans received all of their secured bank loans from a single institution. ${ }^{123}$

Evidence from the field also suggests, albeit somewhat tentatively, that exclusive secured lending relationships are rather unusual. I interviewed seven borrowers with significant amounts of secured debt. These borrowers are sufficiently different to be fairly representative of a large portion of the universe of lending transactions: two publicly traded real estate developers; an industrial tool company; a computer services provider; a late-stage pharmaceutical development, sales, and marketing company; and two privately held real estate developers. Every one of these borrowers indicated that it had outstanding secured debt held by more than one lender. ${ }^{124}$ The consensus from such a wide variety of borrowers provides persuasive evidence that exclusive secured lending relationships are quite rare. ${ }^{125}$

Accordingly, whatever the benefits of exclusive lending relationships might be, the relative rarity of such relationships deprives them of any significant explanatory force with respect to the general pattern of secured credit. This is not to suggest that relationships do not play an important role in the lending market or that they are irrelevant to the decision whether to grant collateral. On the contrary, the effects of relationships are crucial to the structure of lending transactions. ${ }^{126}$ I

123 See Berger \& Udell, supra note 122, at 370-72.

124 See Evans Interview, supra note II2 (transcript at 3-4); Mall Developer Interview, supra note 87 (transcript at I-2); Office Building Developer Interview, supra note 58 (transcript at 2); Pharmaceutical Company Interview, supre note 20 (transcript at 2); Robertson Interview, supra note 44 (transcript at r); Shopping Center Developer Interview, supra note II2 (transcript at 3-4); Telephone Interview with William S.H. Stuart, President, WSHS Enterprises, Inc. (July I2, I995) [hereinafter Stuart Interview] (transcript at 4, on file with the Harvard Law School Library).

125 Of course, such a small sample cannot justify any broad conclusions about the precise frequency of exclusive secured lending relationships. Additional evidence to support this argument is available from the preliminary results of an empirical study of distressed loans. Out of 23 randomly selected loans in which Deutsche Financial Services Corporation elected to terminate the lending relationship, Deutsche Financial Services was the sole secured lender of record in only three cases. The average number of secured lenders of record at the time of Deutsche Financial Services' loan was 3.9. See Mann, supra note 55 (manuscript at 7).

126 Berger and Udell's study, for example, presents statistically significant data suggesting that a ro-year banking relationship would lower the cost of a firm's credit by 48 basis points and the use of collateral from $53 \%$ to $37 \%$ of its loans. See Berger \& Udell, supra note 122, at 369 , 372-75. A more recent study analyzing the terms of bank credit lines reached a similar conclusion, finding that longer relationships lead to lower monitoring efforts and thus indirectly to lower interest rates. See David W. Blackwell \& Drew B. Winters, Banking Relationships and the Effect 
can say, however, that the evidence strongly undermines Scott's characterization of the significance of exclusivity.

\section{B. The Burdens: Why Wouldn't a Borrower Always Secure Its Debt?}

The foregoing discussion once again raises the question of why borrowers do not always secure their debts.127 In light of the advantages of secured credit, answering this question entails identifying the costs of secured credit, the topic of this section. Once both the benefits and burdens have been identified clearly, understanding the decisionmaking processes of borrowers and lenders will be much easier.

Although the precise nature of the burdens of secured credit has been difficult to identify, borrowers typically have a strong preference for the unsecured loan over the secured loan, even if all other significant terms - amount, interest rate, term, and amortization - are equal. Individuals familiar with the preferences of commercial borrowers believe that borrowers will pay a considerable premium to avoid having to grant collateral. Professor Homer Kripke, for example, asserted that his experience in "the factual world" indicated "in no uncertain terms that firms that can avoid giving secured debt do so."128 My research was consistent with Kripke's observation: the various kinds of commercial borrowers and lenders that I interviewed generally evidenced a willingness to accept a significant increase in interest rates to avoid the burdens of a secured transaction. ${ }^{129}$ This anecdotal evidence clearly indicates that a grant of collateral imposes some additional costs.

The burdens that secured credit imposes on borrowers do not explain the variation in the use of secured credit. To understand why some borrowers, but not others, secure their debts despite the costs, an exploration of how the burdens of secured credit actually arise is necessary. This section explores two general ways in which secured credit could increase the aggregate burden of loan transactions: first, by increasing the costs of closing loans; and second, by increasing the costs of administering loans. I conclude that there are two significant costs of secured credit. The first is the increase in information costs associ-

of Monitoring on Loan Pricing 17-20 (Mar. 1996) (unpublished manuscript, on file with the Harvard Law School Library).

127 See supra notes $5-7$ and accompanying text (discussing the ubiquity puzzle of secured credit posed by Alan Schwartz and Barry Adler).

128 Kripke, supra note 15 , at 969.

129 See Evans Interview, supra note r12 (transcript at 9-10) (preferring that his company pay an interest rate premium of about two percent per annum to avoid having to grant a security interest in connection with a working-capital loan); Pharmaceutical Company Interview, supra note 20 (transcript at 3-4) (stating that he would be interested in an interest rate increase of one percent per annum if his inventory lender would forgo taking a security interest in his inventory). 
ated with closing a secured transaction, at least in the context of public companies. The second, which is not limited to public companies, is the increase in administration costs due to the lender's power to prevent the borrower from using its assets in the most profitable way.

t. The Costs of Closing the Transaction. - This section evaluates the possibility that secured credit makes lending transactions more costly by increasing the costs of closing those transactions. I consider three separate types of closing costs: information costs, documentation costs, and filing fees.

(a) Information Costs. - In the course of closing any type of lending transaction, both parties incur significant information costs. The borrower incurs information costs in identifying and analyzing the various financing products available in the market. The lender incurs costs in investigating the merits of the transaction. The lender typically investigates the financial strength or creditworthiness ${ }^{130}$ of the borrower with some care. ${ }^{131}$ A secured lender relying on the value of the collateral as a significant source of repayment also has an incentive to investigate the collateral. ${ }^{132}$ The likelihood that both secured and unsecured lenders will incur considerable investigation costs makes it difficult to ascertain how information costs in the secured

130 Financial strength and creditworthiness are not entirely objective concepts. In this Article, I generally refer to the "strength" or "financial strength" of a borrower to indicate the group of attributes that enhance the perception of lenders and the financial markets that the borrower will repay its debts as promised. Rating agencies analyze these attributes for public companies in great detail. See, e.g., S \& P'S Ratings GRoup, Standard \& PoOR's Corporate Finance CRITERIA 3-4 (I994) (describing the role of ratings in evaluating securities); WILsON \& FABOzZI, supra note II 4 , at 23 ("A bond rating is an indicator or assessment of the issuer's ability to meet its principal and interest payments in a timely manner in accordance with the terms of the issue.").

131 See WILSON \& FABOzZI, supra note $\mathrm{II}_{4}$, at 23-44 (explaining how ratings are determined). In some kinds of heavily asset-based transactions, such as purchase-money loans on automobiles, the lender might forgo any serious investigation of the credit of the borrower because of the decision to treat the collateral as the primary source of repayment in the event of default. Also, a sophisticated unsecured lender might forgo the costs of investigating credit case by case and instead charge an interest rate that reflects its assessment of the likelihood of default over the whole population of borrowers that have not been investigated on an individual basis. For example, credit card issuers come close to following this course. Even in that context, however, the issuers rely on relatively sophisticated analyses of the likely creditworthiness of the relevant population. See Elizabeth Warren, Mortgaging the Future: The Consumer Debt Binge of the 1980s, at Io5-I2 (Aug. 1994) (unpublished manuscript, on file with the Harvard Law School Library); see also Saul Hansell, Merchants of Debt: This Credit Card Is Tailored to You, N.Y. TImEs, July 2, I995, \& 3, at I (discussing increasingly sophisticated methods for estimating the creditworthiness of potential credit card customers).

132 If the lender is taking the collateral for reasons unrelated to its value - to inhibit subsequent lending, for instance - the lender might forgo substantial investigation of the collateral. Even in these cases, however, the lender is still likely to ascertain whether there were any prior security interests in the collateral. See, e.g., DeKunder Interview, supra note 58 (transcript at 28-29) (explaining that the bank would do a U.C.C. search, even if it were not relying on liquidation of the collateral, simply "to have some control"). 
lending context compare with analogous costs in the unsecured lending context.

Although my research does not support any general predictions about the situations in which information costs will be relevant to the secured credit decision, it does shed light on the lending decisions of publicly traded companies. The clearest evidence comes from an interview with the chief financial officer of a publicly traded real estate investment trust with a market capitalization of about one billion dollars. ${ }^{133}$ In order to obtain financing for his company at the lowest possible cost, he carefully evaluates the relative costs of transactions. ${ }^{134}$ Based on his experience, he told me that the "all-in"135 transaction costs of producing a typical ten-million-dollar unsecured loan for his company would be in the range of seventy-five basis points ${ }^{136}$ (three-quarters of one percent of the loan amount). ${ }^{137} \mathrm{He}$ then stated that a comparable secured transaction ${ }^{138}$ would cost about 150 to 200 basis points. ${ }^{139} \mathrm{He}$ explained that the difference in costs arose from the large charges for appraisals and title company charges that his company would incur in the secured transaction. ${ }^{140}$

These costs, of course, are primarily the costs of acquiring information about the value of the collateral and the borrower's title to it. In an unsecured transaction, creditors focus on the creditworthiness of the borrower as a whole. When the borrower is publicly traded, creditors readily can obtain information without any additional expense,

133 See Robertson Interview, supra note 44 (transcript at $\mathrm{I}$ ).

134 See id. (transcript at 3-4).

135 See id. (transcript at 3). This figure includes fees to investment bankers and lawyers, closing costs, and all other costs attributable to the transaction. See id.

$136 \mathrm{~A}$ basis point is a "measure for interest rates and bond yields." A single "basis point equals one-hundredth of a percent (.or percent)." SUSAN LEE, ABZs of MONEY \& FinANCE 35 (I988). Analysts use basis points typically "to measure small changes in interest rates." ENCYCLOPEDIA OF BANKING \& FiNANCE 133 (Charles J. Woelfel ed., roth ed. 1994).

137 The treasurers of two large, publicly traded manufacturers provided similar estimates. See Kimmins Interview, supra note 67 (transcript at 5) (stating that capitalized transaction costs resulted in an overall increase in the cost of debt of about Io basis points per year); Manufacturer Treasurer Interview, supra note 54 (transcript at 4) (estimating 100 basis points in total up-front transaction costs).

$138 \mathrm{He}$ referred to a \$ro million "specimen" mortgage on a single freestanding shopping center with a loan-to-value ratio of $70 \%$. See Robertson Interview, supra note 44 (transcript at 21 ).

$139 \mathrm{See} i d$. He also indicated that the difference in cost would be even greater if the transaction were a large, underwritten issue. He estimated that a large-denomination unsecured offering for his company would have total transaction costs of about 300 basis points, whereas the analogous secured transaction (a collateralized mortgage obligation) would be "probably twice as expensive." Id. (transcript at 3-4).

140 See id. (transcript at 2, 4). Senior bank lending officers who specialize in loans to relatively large borrowers attributed high secured debt costs to similar factors. See Telephone Interview with Cynthia C. Sanford, Senior Vice President, NationsBank of Texas, N.A. (July 20, 1995) [hereinafter Sanford Interview] (transcript at $\mathrm{I7}$, on file with the Harvard Law School Library); Wendel Interview, supra note 40 (transcript at 16). 
either from filings required by the securities laws or from the efforts of analysts evaluating the value of the company's outstanding securities. ${ }^{141}$ Therefore, the existence of detailed financial information about public companies can make unsecured loan transactions considerably less expensive than comparable secured transactions. ${ }^{142}$ This factor provides a significant (and previously unidentified ${ }^{143}$ ) bias in favor of unsecured credit for public companies.

(b) Documentation Costs. - Documenting the transaction is another source of costs. Whether the borrower grants collateral or not, the borrower and the lender incur costs in formalizing the arrange-

141 See Wendel Interview, supra note 40 (transcript at I7) (describing his reliance on "IoQ's, roK's, access to public markets, long operating history ... [j]ust a hell of a lot more public information and available credit information for me to take comfort in"); see also MARK CAREY, Stephen Prowse, John Rea \& Gregory Udell, The Economics of the Private PlaceMENT MARKET at vii (Board of Governors of the Fed. Reserve Sys. Staff Study No. I66, I993) (contrasting the "publicly available information" for "large, well-known firms" with the "information problem" posed by less well-known companies). Indeed, Robertson's comments suggest that publicly traded companies must provide more information to rating agencies monitoring their performance than to their lenders. See Robertson Interview, supra note 44 (transcript at 9).

142 This generalization must be qualified in two ways. First, the principal of a publicly held company that has not yet obtained a rating from the rating agencies explained that the issuance of his company's first publicly traded unsecured debt would be more expensive than the issuance of secured debt because of the costs of educating the market about his company for the first time. See Office Building Developer Interview, supra note 58 (transcript at 5-6). In his circumstances, the unsecured debt seemed to be much more expensive in the short run, although he planned to go forward with the transaction.

Second, the information-cost differential described in the text probably does not extend to small borrowers. Of course, Dun \& Bradstreet and similar businesses do provide credit information about smaller companies, and lenders rely on this information in evaluating loans. See, e.g., NationsBank of Texas, N.A., Business Banking Scorecard Worksheet [hereinafter NationsBank Banking Scorecard] (on file with the Harvard Law School Library) (taking account of the borrower's credit rating); Wirengard Interview, supra note 65 (transcript at 5) (describing his company's reliance on Dun \& Bradstreet reports at the time a lending relationship begins). Hence, there are circumstances in which the costs of acquiring information about collateral will increase the costs of a secured transaction relative to an alternative unsecured transaction. See, e.g., Stuart Interview, supra note 124, at 1o (statement by the Chief Executive Officer of a closely held computer services company) (stating that transaction costs for secured debt are higher than transaction costs for unsecured debt "because of all the brain damage in going out and getting appraisals and all th[e] other [requirements of a secured loan]'). Based on my interviews, however, lenders to smaller companies appear to rely much less on standard credit reports than they do on information that they obtain and evaluate themselves. See, e.g., DeKunder Interview, supra note 58 (transcript at 3-4) (discussing reliance on subjective evaluation of character of borrower); NationsBank Banking Scorecard, supra (describing point ranges in which the officer has discretion to approve or reject the loan, even after the officer evaluates not only the credit bureau report, but also the type of business, the age of the business, corporate structure, and account balances); see also supre note 67 (discussing the risks of relying on credit reports).

143 Although the excellent study by Mark Carey, Stephen Prowse, John Rea, and Gregory Udell provides considerable evidence of the ways in which information problems limit the access of small companies to the public debt markets, see CAREY, PROWSE, REA \& UDELL, supra note I4I, at 15-26, the study does not analyze the relationship between this effect and the use of secured credit. 
ment and reducing it to a set of loan documents that specify the terms of the transaction. On this point, I see no basis for questioning Jim White's conclusion that a grant of collateral will not generally have a significant effect on the costs of documentation ${ }^{144}$ because all but the smallest transactions involve loan documents regardless of whether the borrower grants collateral. And whenever there are loan documents, the lender, as a repeat player, has an incentive to reduce the costs of documentation by developing form documents that can be used in relatively standard transactions. ${ }^{145}$ Although costs may increase as transactions become larger or more complicated, this phenomenon is not dependent on the presence or absence of collateral in the transaction.

Of course, transactions that involve unusual, varied, or widely dispersed collateral might have higher drafting and negotiating costs than transactions that do not involve collateral, but it also is possible to imagine unsecured transactions with particularly high documentation costs. For example, public offerings might face complicated regulatory obstacles imposed by agencies such as the SEC, the IRS, or the EPA. In summary, there is no necessary connection between the existence of security and the level of documentation costs. In most cases, documentation costs will not affect the decision whether to grant collateral.

(c) Filing Fees. - Filing fees are the final category of closing costs. Because unsecured transactions, unlike secured transactions, typically can be made fully effective without any public filing whatsoever, they are generally less expensive than secured transactions. The costs of filing therefore represent a distinct expenditure incurred solely because of the decision to secure the transaction. Compliance with that requirement, in turn, includes not just the actual filing fee, but also all of the costs associated with determining exactly what to file and where to file it. ${ }^{146}$ Nevertheless, the significance of filing fees in the decisionmaking process should not be overstated. ${ }^{147}$ Even in complex transactions, available evidence suggests that these costs are only

144 See White, supra note 15 , at 490 (arguing that inclusion in a particular transaction of a "security agreement likely added trivial costs"). But see Picker, supra note 57 , at 65 I ("The costs of drafting and recording a mortgage increase, rather than decrease, the costs of making the loan.").

145 See Michael Klausner, Corporations, Corporate Law, and Networks of Contracts, 81 VA. L. Rev. 757, 774-89 (I995); Marcel Kahan \& Michael Klausner, Corporate Contracting: Standardization, Innovation and the Role of Contracting Agents 3-16 (Sept. 1995) (unpublished manuscript, on file with the Harvard Law School Library); cf. Kahan, supra note 96, at 586-87 (discussing the pros and cons of standardization).

146 See Steven L. Harris, The Interaction of Articles 6 and 9 of the Uniform Commercial Code: A Study in Conveyancing, Priorities, and Code Interpretation, 39 VAND. L. REV. 179, 212-13 (Ig86).

147 See, e.g., Adler, supra note 7, at 80; Carlson, supra note 73, at 2190 ; White, supra note 15 , at 490 . 
about one twenty-fifth of one percent of the entire loan amount. ${ }^{148}$ To give this number some perspective, one twenty-fifth of one percent of the costs of a $\$ 100,000$ small-business loan would be about $\$ 40$. Amounts in this range would be sufficient to alter the decision only in very rare cases. ${ }^{149}$

In conclusion, neither documentation costs nor filing costs are likely to play a significant role in most decisions about whether to include collateral in a lending transaction. Information costs, on the other hand, are a significant closing cost. These costs strongly encourage unsecured credit in transactions involving large borrowers.

2. The Costs of Administering the Loan. - The borrower's decision to grant collateral also can increase the aggregate costs of the transaction by increasing the costs that the transaction imposes on the parties during the pendency of the loan. ${ }^{150}$ At first glance, the large amounts of time and money that borrowers and lenders spend administering the covenants typically included in documentation for secured transactions would seem to be a significant and obvious cost of secured credit. ${ }^{151}$ But these costs cannot explain the pattern of secured credit, because the parties could avoid the costs by omitting the covenants. Nothing about secured credit obligates the parties to incur these expenditures. The prevalence of such contract provisions therefore suggests that their benefits - which result from their reduction of the lender's pre-loan estimate of the likelihood of nonpayment - outweigh their costs.

To explain the pattern of secured credit, it is necessary to identify an aspect of the secured credit system that is inherent in the grant of collateral. A cost that the parties can avoid by redesigning the docu-

148 See Peter A. Alces, Abolish the Article g Filing System, 79 MiNN. L. Rev. 679, 69I n.39 (1995). Alces's source did not provide sufficient data to determine a precise percentage of the loan amount for the entire sample. Alces's source gives loan amount and U.C.C. filing billings for only five representative transactions, see id., a base of information that is not adequate to justify any reliable generalizations. Nevertheless, the data can provide a rough approximation of the percentage: the billings in the four largest of these five transactions total $\$ 87,940$, which represents $.036 \%$ of the $\$ 242$ million aggregate loan amount $(\$ 87,940 \div \$ 242,000,000=.036 \%)$. See id.

149 That is not to say that filing costs are never relevant. See infra p. 68I (discussing the costs incurred when suppliers file for security interests on products sold to national retailers).

150 I do not consider the costs that secured credit imposes upon default. As discussed above, secured credit is designed to (and probably does) enhance the likelihood that the borrower can be forced to repay the loan upon default. See supra p. 639. Viewed from the joint pre-loan perspective, this enhancement is beneficial because it lowers the sum that is necessary to induce the lender to advance the loan. If the costs of proceeding against collateral in a particular context exceed the costs of pursuing the ordinary remedies available to an unsecured creditor, one would expect the secured creditor simply to pursue recovery directly against the borrower rather than against the collateral.

151 See supra pp. 654-55. 
mentation is not "inherent," because such a cost is not likely to persist unless it is attached to a countervailing benefit of greater value. The most obvious cost that the parties cannot readily "wire around" is a cost tied to one of the most significant benefits of secured credit discussed in section II.A: the leverage that is specially attributable to the grant of collateral. To show how this leverage is a cost inherent in secured credit, this section first explains why the lender might use its leverage to increase the costs of the transaction, and then discusses the difficulties of eliminating the lender's ability to exercise leverage.

(a) The Incentives of the Lender. - As discussed above, one of the most significant problems that the parties must confront in a loan transaction is the differentiation of the borrower's and lender's incentives. ${ }^{152}$ Because the parties will bear and receive differing shares of future losses and gains from the business, their preferences about business decisions will differ.

Earlier discussion explained how secured credit can lessen the costs of the differing incentives by reining in the borrower's tendency toward risky conduct. The division of interests inherent in a loan transaction, however, also moves the lender's incentives away from the ideal (an incentive to maximize the expected present value of the collateral). The lender's disproportionately large share of the downside risk and disproportionately small share of the upside potential give it preferences that are as unduly conservative as the borrower's preferences are unduly risky. A lender that pursues these preferences does more than deter value-decreasing risky transactions; it also deters value-increasing risky transactions. ${ }^{153}$

(b) The Inevitable Costs of Leverage. - One of the most salient features of the secured credit system is that it gives lenders the leverage to induce borrowers to adhere to the lenders' preferences, even with respect to actions not specified in the applicable loan documents. As discussed above, this leverage can provide one of the most significant benefits of secured credit.154 But this leverage also has a negative side, which is much more problematic than prior commentators have

152 See supra pp. 649-58.

153 See Henry Hansmann \& Reinier Kraakman, Hands-Tying Contracts: Book Publishing, Venture Capital Financing, and Secured Debt, 8 J.L. ECON. \& ORG. 628, 649 (1992); Jonathan R. Macey \& Geoffrey P. Miller, Corporate Governance and Commercial Banking: $A$ Comparative Examination of Germany, Japan, and the United States, 48 STAN. L. REv. 73, 77-8I (1995); Scott, supra note 12, at 929; Paul M. Shupack, Preferred Capital Structures and the Question of Filing, 79 MrNN. L. REv. 787, 814 (1995). Strangely, many of the commentators who have observed the unduly risky incentives created for the borrower when debt divides future returns have failed to recognize the equal and opposite effect on the lender's incentives, and thus implicitly have treated the lender's incentives as satisfactory. See, e.g., Adler, supra note 7, at 76-77; Hideki Kanda \& Saul Levmore, Explaining Creditor Priorities, 80 VA. L. REV. 2103, 2108-II (1994).

154 See supra pp. 645-49, 655-56. 
appreciated. ${ }^{155}$ Coupled with the lender's risk-averse preferences, the lender's leverage creates a likelihood that the lender will block the most profitable uses of the borrower's assets and thus increase the aggregate costs of a secured transaction. ${ }^{156}$ Because the borrower is well aware of these potential costs, the borrower views the secured transaction as more costly and thus less advantageous than an analogous unsecured transaction. As one borrower explained, in a secured loan "[y]ou just don't have the same flexibility of dealing with your properties as if you owned them unencumbered."157

As with any aspect of the credit system that imposes costs, it is necessary to ask why borrowers and lenders do not restructure their transactions to avoid the costs. The answer is that the only feasible way to avoid the leverage is to make the transaction unsecured. The lender's ability to force liquidation of the collateral to satisfy the debt is inherent in a grant of collateral. There are only two ways to limit the lender's ability to harm the borrower through exercise of the leverage that arises from the threat of forced liquidation: limiting the losses that accompany liquidation or limiting the lender's opportunities for exercising that leverage to control the borrower's conduct. Neither solution, however, is feasible as a general matter.

The first way to limit leverage would be to limit the amount of the losses that the lender can inflict. The main foundation of the secured creditor's leverage is the differential between the collateral's value to the borrower and the amount that the lender would credit on the loan if the collateral were liquidated under the security agreement or mortgage. ${ }^{158}$ One basis for this differential seems plainly ineradicable: the fact that the value of the collateral in the borrower's business is likely to be substantially greater than the fair-market value of the collateral. ${ }^{159}$ Thus, even if the market for refinancing offered distressed borrowers immediate and costless borrowing up to the full fair-market

155 Several scholars have observed that borrowers lose flexibility when they cede some control of the business to lenders. See Bowers, supra note I2, at 65-67; Carlson, supra note 73, at 2190; Triantis, supra note II, at 248. These scholars have not, however, recognized the importance of the cost because they have not connected it with the differentiation of incentives between borrowers and lenders. Because of the differentiation, the loss of control is not just "inconvenient," see Carlson, supra note 73 , at 2190 ; it causes a significant alteration of the investment preferences that will guide the operation of the business.

156 See Mueller Interview, supra note 54 (transcript at 17 ) (discussing loan officer's caution in accepting proposals from troubled borrowers); cf. Coburn Interview, supra note 54 (transcript at 24) (stating that loan officer's company rejects around ro\% of the requests submitted by borrowers for approval of new leases).

157 Robertson Interview, supra note 44 (transcript at Io); see also Kimmins Interview, supra note 67 (transcript at Io) (explaining that his company's aversion to secured debt rests on "a question of flexibility and having to deal with it").

158 See supra pp. 646-47.

159 However perfectly the market may function to deal with asset-specific investments (such as the investments in the factory in which the asset is located), borrowers will continue to have some 
value of the borrower's assets, borrowers would stand to lose considerably on foreclosure.

The other basis for the differential - the likelihood that liquidation will not even bring the market value - may be more tractable than the first, but it remains beyond the control of the parties. The financial system does not provide immediate and costless financing to distressed borrowers, ${ }^{160}$ and the parties cannot repair the existing secured credit system to increase the value that it returns upon liquidation of collateral. Of course, the borrower can protect itself by purchasing the collateral, but the general illiquidity of defaulting borrowers indicates that in many cases this solution is not practical.

If the parties cannot remove the potential for losses on liquidation, the only remaining avenue for limiting leverage costs is to restructure the transaction in order to eliminate the discretionary opportunities that enable lenders to exercise leverage. This avenue does hold some promise, but it does not provide a complete solution. Theoretically, borrowers could grant a "bare" security interest with no covenants whatsoever. This approach would be impractical, however, because it would deprive the lender of most of the benefits that motivated the decision to take a security interest in the first place. For example, if the bare security interest covered specified assets, the borrower could evade the security interest by the simple expedient of selling the encumbered assets. ${ }^{161}$ Similarly, a bare security interest that covered all of the assets would hinder the borrower's ability to obtain subsequent financing and yet provide none of the incentive-repairing benefits that are the main positive attributes of secured credit. 162

Assuming, then, that the loan documents will contain some covenants, the best approach would be for the borrower to make the terms of the documents as precise as possible in order to limit the likelihood that it will commit technical defaults or be required to obtain the lender's consent to conduct ordinary business operations. My interviews indicate that sophisticated borrowers try very hard to accomplish this goal. ${ }^{163}$ These efforts, however, confront a serious difficulty:

nontangible investments (human capital, emotional attachments, and the like) that will cause them to value the asset more highly than the market would. See supra note 79 .

160 See supra note 74.

161 The textual discussion assumes that the applicable documents would permit the sale of the collateral free of the debt; a restriction on the sale would impose just the sort of limitation on the borrower's flexibility that a bare lien would be designed to avoid.

162 In cases in which the purpose of the lien is to prevent future borrowing, that would not be a problem. See supra pp. 64I-45 (discussing that motivation for secured credit). Accordingly, it is plausible that the bare-blanket-lien approach might be useful in those cases. Preliminary results of empirical research I am conducting suggest that something like that approach occurs in smallbusiness loans from banks.

163 In the context of commercial real estate lending, for example, the borrower often attempts to limit the lender's power to block the disbursement of insurance and condemnation proceeds for 
drafting precise language that allows the lender to prevent excessive risk-taking or outright injury often also leaves the lender with the opportunity to impose its preferences on the borrower. Thus, although sophisticated parties try to limit leverage, they are unlikely to remove it entirely. Indeed, it is a fairly common perception among commercial borrowers and lenders that even conscientious commercial borrowers cannot refrain from committing technical defaults that give the lender the power to take action. ${ }^{164}$ And if the lender always has the power to take action against the borrower, the prospect that the lender will use that power to harm the borrower will increase the borrower's up-front assessment of the cost of the loan. This effect, in turn, will make secured credit less desirable than unsecured credit.

$* * *$

The foregoing discussion of the benefits and burdens of secured credit provides a framework for analyzing how borrowers and lenders decide whether to include collateral in the structure of their transactions. The possible benefits include not only the direct enhancement of the lender's ability to collect its debt forcibly, but also indirect effects that substantially increase the likelihood that the borrower will be in a position to, and choose to, repay the debt without forcible collection. All of these benefits work together to lower the lender's pre-loan perception of the risk of nonpayment, allowing the lender to make a profitable loan at a lower interest rate or on more lenient terms. On the down side, the parties also must consider the corresponding burdens. For large companies, secured credit is likely to carry with it a significant increase in the information costs of the lending transaction. More

rebuilding and the lender's ability to require the borrower to seek the lender's consent for new leases (or significant modifications of old leases) of portions of the collateral. See Coburn Interview, supra note 54 (transcript at 27) (statement of bank's real estate loan officer) (explaining that these provisions are among the ones that borrowers most frequently negotiate); Office Building Developer Interview, supra note 58 (transcript at 12) (stating that "you do your absolute best" in negotiating provisions that require lender approval of leases in an office building); see also Shopping Center Developer Interview, supra note II2 (transcript at I3) (stating that the developer negotiates hard on provisions limiting ability to grant subordinate liens).

164 See Mall Developer Interview, supra note 87 (transcript at 6) (remarking with respect to a recently refinanced project that he "would have to believe there's some minor default that we've made - didn't get a payment in on the first of the month when it was due, maybe got it there on the fifth - technically, it's a default'); Office Building Developer Interview, supra note 58 (transcript at II) (agreeing that remaining in compliance with loan covenants is "relatively difficult" and stating that "[s]ometimes you comply and sometimes you don't"); Shopping Center Developer Interview, supra note I12 (transcript at 14) (acknowledging that he regularly is in default for failure to submit leases to lender for approval as required by loan documents); Stuart Interview, supra note 124 (transcript at 9) (statement of the Chief Executive Officer of a closely held computer services company) (asserting that "[t]here might be some people that are always in default" and that "[t]here are some covenants of the loan that I sometimes don't adhere to"). 
generally, secured credit imposes costs on all borrowers - large and small - by diminishing their operating flexibility.

\section{The Pattern of Secured Credit}

Because secured credit provides both benefits and burdens to the parties that use it, any explanation of the pattern of its use must involve an analysis of its benefits and burdens in different contexts. This Part applies the decision-based model set forth in Parts I and II to three separate aspects of the pattern of secured credit: the wellknown fact that the strongest companies use secured credit with relative infrequency; the relation between the use of collateral and the duration of the debt; and the apparently low rate of retention of security interests by suppliers.

\section{A. Unsecured Debt of Strong Companies}

I. The Puzzle. - Although empirical evidence about the details of the pattern of secured credit is relatively limited, a significant amount of empirical and anecdotal evidence supports one overarching generalization: there is a connection between the riskiness of a borrower and the borrower's decision to grant collateral. ${ }^{165}$ Whether the borrower is large or small, doubts about the firm's financial structure tend to be associated with secured debt. 16.6 Conversely, unsecured debt is not limited to large companies; even small, privately held firms issue unsecured debt in appropriate circumstances. ${ }^{167}$

165 See, e.g., Berger \& Udell, supra note 15 , at $27-40$ (concluding, based on a study of Federal Reserve data on over one million business loans, that collateral is more frequently granted on riskier loans); see also Leeth \& Scott, supra note 107, at 389 (noting that the presence of unsecured debt is associated with the age of a firm and arguing that age is a proxy for diminishing riskiness). For evidence that the use of security interests in Japan rises with the riskiness of the loan, see TOSHIHRO HorIUCHI, MAIN BANK COMPETITION AND THE LOAN MARKET 48-60 (1988), which bases its conclusion on a $1983-84$ survey of 8000 small and mid-sized Japanese companies. For anecdotal evidence, see Berger \& Udell, cited above in note 15, at 27 , which describes the "conventional wisdom in banking which holds that riskier borrowers are more likely to pledge collateral," and Kripke, cited above in note 15 , at 944 n.48, which states that it "fre. quently happens [that a business] becomes profitable enough to graduate to unsecured credit."

166 See, e.g., Robertson Interview, supra note 44 (transcript at $17-19$ ) (describing various reasons why publicly traded companies issue secured debt); White, supra note 15 , at 473-75 (discussing a grant by Pan American World Airways of security interest in aircraft); see also LoPucki, supra note 8, at $1928-29$ (predicting that large companies will grant security "when the threat of [tort] claims is significant").

167 See, e.g., James R. Booth, Contract Costs, Bank Loans, and the Cross-Monitoring Hypothesis, 3 I J. FIN. ECON. 25, 32 (r992) (presenting the findings of a study of almost 800 commercial loans indicating that over $40 \%$ of the loans issued by firms with privately held equity were unsecured); Leeth \& Scott, supra note 107, at 387 (suggesting, based on a random sampling of 500,000 members of the National Federation of Independent Businesses, that more than $35 \%$ of the loans were unsecured); DeKunder Interview, supra note 58 (transcript at 12-r3) (discussing the practice of making an unsecured loan to allow a small business to purchase equipment). 
2. Earlier Explanations. - Given the likelihood that creditworthy companies are financially sophisticated and given the obvious benefits that secured transactions can offer in some contexts, any useful discussion of the pattern of secured credit must provide a coherent explanation for the general dearth of secured credit among companies with excellent credit ratings. Although that puzzle has attracted the attention of several scholars, none has provided a satisfactory explanation of the empirical evidence. ${ }^{168}$

The most sustained attempt to explain the relative absence of secured debt from the balance sheets of certain companies is Barry Adler's I993 article in the Journal of Legal Studies. ${ }^{169}$ In contrast to the decision-based model presented above, Adler's analysis does not identify any costs attributable to secured credit.170 Accordingly, he cannot ascribe the use of unsecured credit to any defects in secured credit. Instead, he ascribes the existence of unsecured credit to the potential for unsecured creditors to provide monitoring that benefits equity investors, thus linking unsecured lending to firms with dispersed equity investors. ${ }^{171}$

This analysis suffers from several basic flaws. First, at a theoretical level, Adler cannot explain why the interests of unsecured creditors should match the interests of equity investors so closely that equity investors would trust unsecured creditors to protect them. Because the unsecured creditors' share of the risks of the business differs qualitatively from the equity investors' share, monitoring by unsecured creditors is unlikely to provide adequate protection to dispersed equity investors. ${ }^{172}$

168 Neither of the major empirical studies identifying the connection between collateral and risk undertakes to provide a theoretical explanation. Berger and Udell simply note that their empirical result "is not the result predicted by the majority of theoretical studies." Berger \& Udell, supra note 15 , at 40 . None of the studies that they cite explains the correlation between risk and collateral. See id. at 23-27 (discussing prior literature). Leeth and Scott come the closest to understanding the relationship when they suggest in passing that "firms with high probabilities of bankruptcy will find that the benefits of secured debt outweigh the costs, while firms with low probabilities of bankruptcy will find that the costs outweigh the benefits." Leeth \& Scoth, supra note I0\%, at 383. Leeth and Scott do not, however, explain why firms will draw that conclusion.

169 Adler, supra note 7.

170 "The only cost necessarily attributable to secured, as compared to unsecured, credit is that from the ministerial task of public recordation." Id. at 79 .

171 See id. at 89-98.

172 Cf. Shupack, supra note 49 , at 782 n.I6 (arguing that secured creditor monitoring will not help unsecured creditors). Adler addresses this point at length, see Adler, supra note 7, at 87-94 (acknowledging that secured creditor monitoring will not help equity holders, but arguing that unsecured creditor monitoring will), but he does not acknowledge the differentiation of incentives between unsecured creditors and equity investors. This differentiation suggests that equity investors are unlikely to rely seriously on monitoring by unsecured creditors. In fact, the little direct empirical evidence that exists strongly undercuts Adler's thesis. Randall Morck and Masao Nakamura have concluded, based on a regression study of large Japanese firms in the rg80s, that leading unsecured creditors of Japanese firms are much more likely to intervene to protect their 
Second, even Adler never argues that the dispersed holders of publicly traded unsecured debt are any more capable of monitoring than the dispersed equity investors themselves. Rather, he is reduced to arguing that the benefit of the unsecured debt comes from the pre-loan investigation conducted by investment banks underwriting the debt for the dispersed parties that will buy it. ${ }^{173}$ It is difficult to see, however, why that investigation should be any more thorough than the investigation that precedes an equity issue. Indeed, contrary to Adler's thesis, my interviews suggest that monitoring by third parties rating equity issues tends to be more intrusive than monitoring by debt, not less intrusive. ${ }^{174}$ Also, as Adler himself acknowledges, his thesis does nothing to explain the evidence related to small firms with unsecured debt: ${ }^{175}$ contrary to the prediction that Adler offers, many firms without widely dispersed investors do issue unsecured debt. 176

Finally, the fundamental difficulty with Adler's thesis is that his attempt to tie unsecured credit to public ownership does not match the empirical evidence about unsecured debt. This evidence links unsecured credit to low risk, which is quite distinct from public ownership. Because Adler explains a relationship that is different from the one that occurs in the marketplace, his analysis has little value in revealing the actual pattern of secured credit.

Bob Scott and Lynn LoPucki also have addressed the question in passing in the course of scholarship devoted to other topics, but their suggestions fit the evidence no better than Adler's. Scott suggests that the predominance of unsecured debt in large companies is attributable to their ability to "exploit the economies of scale necessary to [assess the risks and] effects of financial decisions."177 That explanation, how-

interest in being repaid than to protect stock prices in general. See RANDALl MORCK \& MASAO Nakamura, Banks and Corporate Control IN Japan 30-3I (Institute for Fin. Research, Faculty of Bus., Univ. of Alberta, Working Paper No. 6-92, 1994) (on file with the Harvard Law School Library); see also Macey \& Miller, supra note 153, at 82-84 (discussing the Morck and Nakamura study).

173 See Adler, supra note 7 , at 90-92.

174 See Robertson Interview, supra note 44 (transcript at 9); see also KaHAN \& TucKMaN, supra note 97 , at $17-23$ (presenting empirical evidence of the relative ineffectiveness of monitoring of borrowers through publicly traded unsecured debt agreements).

175 See Adler, suppra note 7 , at 89 n.66 ("[T]he arguments that follow offer no explanation for the use of unsecured credit in small firms with unencumbered but encumberable assets.").

176 Adler predicts that "discretionary unsecured credit," by which he means unsecured credit issued "despite the availability of unencumbered encumberable assets," will vary directly with the concentration of a firm's equity interest. Adler, supra note 7, at $96 \&$ n.85. For contrary empirical evidence, see notes 166 and 167 above, which discuss the issuance of secured debt by public firms and unsecured debt by private firms.

177 Scott, supra note I2, at 94I. It is not clear how to relate this comment to Scott's general argument that secured lending benefits borrowers by fostering exclusive lending relationships. See supra pp. 656-58 (criticizing that argument). I take Scott's comment as his justification for the perceived absence of those beneficial secured lending relationships from large companies. 
ever, is belied by the frequent issuance of unsecured debt by small companies. ${ }^{178}$ Just as Adler errs in directing his focus to the borrower's organizational structure, Scott errs in attempting to explain the pattern of secured credit through reference to the borrower's size rather than its financial strength. Because the empirical evidence suggests that the touchstone is strength, ${ }^{179}$ Scott's explanation is unpersuasive.

Lynn LoPucki argues that, when the managers of large companies issue unsecured debt, they "sacrific[e] the best interests of their companies to render their own positions less precarious."180 That argument rests on the dubious premise that the entire institution of unsecured lending to this nation's strongest companies is in fact harmful to the companies' shareholders. LoPucki's premise is difficult to reconcile with my research, which indicates that the agencies that watch strong companies most closely not only refrain from criticizing unsecured credit, but in fact demand it. For example, the chief financial officer of one publicly rated borrower explained that his company had worked hard to get rid of its secured debt because the rating agencies had "insisted" on his company's compliance with a strict limitation on secured debt. ${ }^{181}$ This type of anecdotal evidence, coupled with the strong theoretical evidence about the costs of secured credit adduced in section II.B, indicates that a strong company's unsecured borrowing is more likely to be related to the relative advantages of that transaction than to a supposed pattern of persistent misconduct by corporate managers.

3. Decision-Based Analysis. - Considered in light of the decision-based model presented above, the solution to the puzzle of the unsecured debt of strong companies is obvious. As explained in section II.A, the benefits of secured credit work together to reduce the parties' pre-loan expectation of default. With respect to strong companies, that reduction is quite limited. ${ }^{182}$ When a company has a strong balance sheet, ${ }^{183}$ the lender advancing funds may view the risk of non-

178 See supra note 167.

179 See supra note 165 .

180 LoPucki, supra note 8 , at 1930 .

181 See Robertson Interview, supra note 44 (transcript at $\mathrm{r}$ ).

182 I am not the first to suggest that the pattern of secured credit is influenced by the inverse relationship between the benefits of secured credit and a firm's financial strength. See Triantis, supra note II, at 256-57. Although insightful, Triantis's relatively abstract analysis does not explain how financial strength influences a borrower's decision to choose unsecured credit. Moreover, his analysis focuses on a very limited number of the factors that influence the decision, thus obscuring the wealth of relevant considerations that this Article identifies.

183 For a discussion of what I mean when I refer to a company as "strong," see note I30 above. 
payment as insignificant ${ }^{184}$ even in the absence of collateral. 185 In cases in which that is true, a grant of collateral - however solid can do little to decrease the lender's (already minimal) perceived risk of nonpayment. ${ }^{186}$ The idea that the credit quality of many borrowers who obtain unsecured loans is so high that the loans are extraordinarily safe is consistent with several earlier empirical studies; these studies suggest that unsecured bank loans tend to have lower risk premiums and less frequent defaults than secured bank loans. ${ }^{187}$

184 Nonetheless, publicly traded companies occasionally go into bankruptcy with large amounts of unsecured debt. See LoPucki, supra note 8, at 1927 n.I53 (examining 42 large publicly traded bankrupt debtors that had bank debt outstanding at the time of their bankruptcy filings and observing that 28 had wholly or substantially unsecured bank debt). But that does not prove that lenders err in their general willingness to make unsecured loans to companies of apparent strength. There is always some risk of default, no matter how strong the borrower is at the time of the loan. See Edward I. Altman, Measuring Corporate Bond Mortality and Performance, $44 \mathrm{~J}$. Fin. 909, 9I5 (I989) (reporting a study indicating a cumulative rate of default of $0.13 \%$ for AAAgrade bonds during the first ro years after the date of issuance).

185 The market demonstrates the relation between interest rates and the borrower's creditworthiness by producing lower interest rates on bonds that are sold by companies with higher credit ratings. See, e.g., S \& P's RATINGS Group, supra note 130, at 3; Kahan, supra note 96, at 592. My interviews produced evidence that supports the existence of this connection, even for relatively small borrowers. See, e.g., DeKunder Interview, supra note 58 (transcript at 9-12) (discussing a willingness to deviate downward from a bank's standard interest rates for customers with strong credit records); Telephone Interview with Anonymous Loan Officer, Anonymous Middle-Market Bank Lender (July 17, 1995) [hereinafter Middle-Market Banker Interview] (transcript at 5, on file with the Harvard Law School Library) (stating that "pricing . . . definitely would have been higher" on her most recent loan if the borrower had been "weaker"). A firm's creditworthiness is a function of the size of the loan relative to the firm's ability to repay the loan. Even the most creditworthy companies could seek loans of such a large amount, or with such a lengthy term, that the lender would have serious doubts about the certainty of repayment. In those cases, my analysis predicts that the parties would agree to grant collateral. See infra note 208 (discussing difficulties that strong companies face in issuing long-term unsecured debt).

186 For example, the treasurers of two large manufacturing companies were skeptical of the idea that a grant of collateral could increase the perceived likelihood that their companies would repay their loans. One treasurer explained: "I think there'd be practically no value compared to our current credit quality, practically no value to doing an offering secured by [a grant of collaterall." Kimmins Interview, supra note 67 (transcript at II). The other treasurer stated:

[L]ook at the long-term borrowing we just did recently, where we borrowed at roughly 35

to 40 basis points above the comparable U.S. Treasury. Absent some kind of a tax-struc-

tured financing, nobody is going to borrow cheaper than the U.S. government, so there

isn't a lot of room there to reduce the cost by securing assets . . . .

Manufacturer Treasurer Interview, supra note 54 (transcript at 7).

187 See Berger \& Udell, supra note 15, at 27-40 (discussing a study of Federal Reserve data on over one million loans and reporting a positive correlation between the existence of collateral and both interest charges and rate of default); Blackwell \& Winters, supra note 126, at 13-14 (presenting a study of $\mathrm{I} 74$ bank lines of credit that indicated a statistically significant connection between the existence of collateral and a $0.33 \%$ per annum increase in the interest rate); Booth, supra note 167 , at 36 (presenting a study of more than 1100 commercial loans and reporting a positive correlation between the existence of security and the size of the interest rate); Yair E. Orgler, A Credit Scoring Model for Commercial Loans, 2 J. Money, CREDrT \& BANkING 435, 440 (1970) (presenting a study of 300 loans chosen randomly from the portfolio of East Coast banks suggesting a 
Looking to the other side of the ledger, there is no reason to think that the creditworthiness of a borrower generally will decrease the burdens of secured credit. The principal general cost of secured credit is the cost to a borrower of enduring supervision by a third party not directly motivated to maximize the enterprise's profit. ${ }^{188}$ That cost harms a creditworthy borrower just as much as a borrower of questionable strength. Indeed, if the more creditworthy borrowers are also more sophisticated, the costs of the supervision might be even greater. For example, knowledgeable borrowers are more likely than weaker borrowers to engage in the kind of deliberate assessment of risks that might cause lenders to oppose value-increasing decisions. Also, because knowledgeable borrowers may be more aware of the burdens that a secured transaction might create over the course of performance, they may be more likely to account for those burdens in evaluating the total cost of the transaction.

In addition to that general risk-based explanation, the ready availability of information about public companies enhances the relative advantage of unsecured credit for those companies in two specific ways. First, unsecured transactions rely on information about the firm's general financial strength that is available without significant additional expense; secured transactions, by contrast, require asset-specific information that needs to be generated for each transaction. ${ }^{189}$ Second, public companies have a strong interest in maintaining a good reputation for creditworthiness because they depend on frequent access to the financial markets. ${ }^{190}$ This interest gives even unsecured creditors significant leverage over those companies, thus lessening the relative benefit to those creditors of a secured transaction. ${ }^{191}$ A major unsecured lender that declares a default against such a borrower could inflict substantial harm on the borrower - without regard to the lender's ability to liquidate the borrower's assets - because the declaration of default would be likely to limit the borrower's future access

positive correlation between the existence of collateral and the likelihood that bank examiners would criticize the loan).

My interviews with lenders produced additional evidence to support the idea that unsecured loans are safer than secured loans. Specifically, two lenders who make both secured and unsecured loans indicated that they believed that, after taking account of expenses, unsecured loans tend to produce a higher rate of repayment, whether through voluntary payments, litigation, or foreclosure. See DeKunder Interview, supra note 58 (transcript at 26) ("I would think that our experience . . . in unsecured loans might be better than secured loans, because we make unsecured loans typically to the more creditworthy customers."); Mueller Interview, supra note 54 (transcript at I4-15) (explaining that most of his bank's losses during the last recession were on secured loans).

188 See supra pp. $663-67$.

189 See supra pp. 660-6r.

190 See supra note 70 and accompanying text.

191 See supra note 88. 
to the funds that it needs to operate its business. ${ }^{192}$ To the extent that many of the strongest companies are publicly traded, that effect reinforces the other factors discussed above.

In sum, as a borrower's financial strength increases, secured credit becomes a less attractive alternative: its benefits decrease and its costs, at best, remain constant. Responding to this effect, borrowers exhibit an increasing tendency toward unsecured debt as their financial strength increases. ${ }^{193}$

\section{B. Long-Term Debt and Collateral}

The relation between the existence of collateral and the term of the loan has preoccupied commentators ever since Jackson and Kronman's I979 prediction that "one would expect long-term loans to be made on a secured basis more frequently than short-term loans."194 Jackson and Kronman rested that prediction on their view that monitoring is the chief reason for secured credit and their belief that a debtor has "more opportunities ... for subtle forms of misbehavior" during loans with longer periods. ${ }^{195}$ Although some scholars have supported this analysis, ${ }^{196}$ others have attacked it on a variety of grounds. For example, Kripke has argued, contrary to Jackson and Kronman's premise, that short-term credit can be just as risky as long-term credit. 197 Others have contended that Jackson and Kronman's analysis produces predictions that do not comport with reality. ${ }^{198}$

192 The effectiveness of reputation-based leverage depends on the borrower's need to return to the market frequently and the market's rapid dissemination of information about them. First, the need to return to the market enhances the significance of reputation to the borrower. See Charny, supra note 56, at 393; Shell, supra note 120, at 268-69. Second, "improper" actions by a borrower, such as a default, will affect the borrower only if the market disseminates that information effectively. See Charny, supra note 56, at 420; Shell, supra note 120, at 269-71.

193 My analysis does not preclude the possibility that strong borrowers could benefit from the issuance of secured debt. For example, even companies with impressive credit ratings may find obtaining long-term unsecured debt expensive. In those cases, the grant of collateral can reduce the costs of financing considerably. See infra note 208.

194 Jackson \& Kronman, supra note 5, at Ir59.

195 Id.

196 See, e.g., Buckley, supra note I2, at 1444 \& n.102 ("The risk of debtor misbehavior also seems proportional to the length of the loan. ... [T]he reality that banks, the most typical secured creditors, are generally long term creditors . . . support[s] the costly monitoring hypothesis."); Leeth \& Scott, supra note 107, at 384 .

197 See Kripke, supra note 15 , at 949-50; see also Adler, supra note 7 , at 80-81 (arguing that Alan Schwartz understates the degree of risk associated with short-term loans).

198 See, e.g., Steven L. Harris \& Charles W. Mooney, Jr., A Property-Based Theory of Security Interests: Taking Debtors' Choices Seriously, 80 VA. L. REV. 202 I, 2028 n.r7 (1994) (asserting that "examples of long-term unsecured debt abound"); Schwartz, supra note 5, at 13-14 (arguing that Jackson and Kronman's thesis is "seriously embarrassed" by the substantial amount of short-term secured debt). 
To make sense of the relation between collateral and the term of a loan, ${ }^{199}$ it is necessary to start by considering the scanty empirical evidence that is available. John Leeth and Jonathan Scott conducted the only full-scale empirical study on the topic of which I am aware. They examined 2500 responses to a questionnaire sent to members of the National Federation of Independent Businesses (a small-business trade group). ${ }^{200}$ Leeth and Scott concluded that there is a statistically significant correlation, albeit a small one, between the existence of secured credit and the length of the loan term: the longer the loan, the more likely it is to be secured.201

The most important point that I draw from the relatively small effect that Leeth and Scott identify is that the economy contains a substantial amount of all of the relevant categories of debt: long-term secured, long-term unsecured, short-term secured, and short-term unsecured. This statistical conclusion should not be surprising. Anyone familiar with the commercial marketplace can think of common transactions in each of the four categories: long-term secured commercial real estate mortgages; long-term unsecured corporate bonds; short-term

199 I acknowledge a certain subjectivity inherent in any discussion of the term of a loan. Many loans normally characterized as short term, because the lender has the right to demand immediate payment at any time, might as a practical matter involve relatively lengthy relationships. See Schwartz, supra note 5, at 12-13. On the other hand, loans that have a long stated term will not necessarily involve a relationship of that length because of the possibility that the loan will be called or repaid before the stated maturity date. Nevertheless, the distinction between a loan that is payable on demand (or after a short stated period like 30 to 90 days) and a loan that is not payable for decades unless the borrower defaults is sufficiently substantial to justify considering the relation between this distinction and collateral. My belief that the distinction has significance is supported by evidence from my interviews that both borrowers and lenders regard the length of the stated term as a crucial factor in evaluating proposed loan transactions. See, e.g., Kimmins Interview, supra note 67 (transcript at 4-5) (statement by the treasurer of a Fortune Ioo manufacturing company) (stating that the interest rate that his company pays to borrow money with a maturity of 20 years is about 35 basis points higher than the rate that the company would pay to borrow money with a maturity of one year); Massie Interview, supra note 54 (transcript at 2-3, 5) (statement by the investment officer for a life insurance company) (expressing his concerns about negotiating an unsecured loan with a term of 20 years).

200 See Leeth \& Scott, supra note I07, at 386. Two other studies upon which this article relies, Berger and Udell's study and Booth's study, also considered the duration of the loan, but they correlated it only against the risk premium and not against the existence of collateral. See Berger \& Udell, supra note 15 , at 30-3I; Booth, supra note 167 , at 36 .

201 Leeth and Scott analyzed data from two years, rg80 and 1982. The rg8o data suggested that a one-year increase of the term of a loan would increase the likelihood of collateral by $3.6 \%$; an increase of the term of one standard deviation above the mean increased the likelihood of collateral by 12.1\%. See Leeth \& Scott, supra note 107, at 389. The findings related to term were statistically significant at the $I \%$ level. See $i d$. at 390 . The figures from 1982 suggested an even smaller effect. See id. at 389 (reporting that a one-year increase in term generated a $1.4 \%$ increase in the probability of collateral and that an increase of one standard deviation created a $6 \%$ increase). For a less detailed study from Japan that reaches a similar conclusion, see HoRIUCHI, cited above in note 165 , at $51-52$, which presents statistical evidence that in Japan the prevalence of real estate as collateral for a loan increases with the term of the loan. 
secured working-capital loans; and short-term unsecured commercial paper. Accordingly, the statistical evidence, coupled with anecdotal impressions of the marketplace, seriously undermines any explanation of security that predicts that any of those categories would be nonexistent or even rare. Nevertheless, one question still remains: why is there any connection at all between the length of the loan and the presence of security? My answer to this question, like my answer to the strong-company problem in section II.A, focuses on the capacity of collateral to decrease the lender's pre-loan assessment of risk.

Strong companies tend to issue relatively little secured debt because a grant of collateral provides no significant benefit to the parties. ${ }^{202}$ In the context of long-term lending, on the other hand, granting collateral can provide a significant benefit to the parties. Whether a company's strength will endure for decades into the future is quite difficult to predict. In our increasingly unitary global economy, all but the most unusual companies face risks from competition, development of new technologies, alteration of consumer demands, or departure of key personnel. ${ }^{203}$ Hence, when a lender relies on a company's general strength for repayment, the lender's pre-loan assessment of the risk of nonpayment should rise significantly as the term of the loan increases. ${ }^{204}$ In contrast, many types of collateral are relatively likely to retain their value into the future. For example, a single Manhattan office building is much more likely to retain its value for thirty years than is the balance sheet of the developer that owns it. ${ }^{205}$ Hence, even for borrowers of redoubtable current strength, a grant of a lien on a particularly durable asset could decrease the aggregate costs of a long-term transaction significantly. Conversely, on the cost side, as with loans to strong borrowers, there is no general reason to

202 See supra section III.A.

203 See, e.g., RUTH, supra note 55, at 249; infra note 208 (discussing the market perception of the long-term risks for Hewlett-Packard).

204 See Kimmins Interview, supra note 67 (transcript at 4-5) (statement of the treasurer of a Fortune roo manufacturer) (describing a schedule of increases in the default-risk premium that his company pays as the term of the loan increases); RUTH, supra note 55, at 248-49 (American Bankers Association textbook) (listing the term of the loan as one of eight factors that a loan officer should consider in deciding between a secured and unsecured loan). One bank officer explained the problems of extending the term of an unsecured loan: "You may have a borrower who's very strong and very liquid, and you make a loan on an unsecured basis, a loan that spans a two or three year period of time. During that period of time, their financial condition can change dramatically." Coburn Interview, supra note 54 (transcript at 4).

205 See Hamstra Interview, supra note 70 (transcript at 6) (statement of an insurance company lender) (explaining that she is more comfortable about the long-term values of specific assets on which she has a lien than about the company's long-term general credit); see also DeKunder Interview, supra note 58 (transcript at 7-9, 13) (explaining that the institution's standard products for secured small-business loans generally have a longer term than standard products for unsecured business loans of a comparable size to comparable borrowers, and that five years "would be the outside on an unsecured loan" to a small business). 
believe that the burdens of secured credit will increase as the term of the loan increases. ${ }^{206}$

This pattern of factors - increasing benefits from secured credit without any change in its burdens - is consistent with the observed increase in the use of collateral as the term of the debt increases. Indeed, the correlation between financial strength and unsecured debt should strengthen as the term of the loan increases. Companies of varying strength should be able to obtain short-term unsecured debt based on current business patterns, but companies of questionable financial strength should rarely be able to issue long-term unsecured debt. ${ }^{207}$

This framework also offers a ready explanation for the substantial amount of long-term unsecured debt. Long-term unsecured debt makes sense when the company's financial condition is strong enough to minimize the possible benefits of secured credit, even considered over a long term. Current strength is not enough; the borrower must be able to persuade lenders that its financial strength is not likely to diminish over time. ${ }^{208}$

In sum, my evaluation of the empirical evidence in light of my decision-based model suggests a relation not all that different from Jackson and Kronman's: a preference for collateral that increases significantly with the term of the loan. The empirical grounding of my explanation, however, makes it significantly more plausible and valuable than their more tentative theoretical explanation.

\section{The Unsecured Debt of Inventory Suppliers}

One of the most common topics in the debate about secured credit has been the relations between trade creditors and the businesses to which they sell. Almost all of the scholars have started with the question that Jackson and Kronman first asked: why do inventory suppli-

206 If anything, my interviews suggest that the relative burdens of secured credit fall as the term of the loan increases because a longer term spurs unsecured lenders to toughen their documents. See Massie Interview, supra note 54 (transcript at 2-3, 5) (describing how the inability of his company to agree on appropriate loan covenants for a 20-year unsecured loan to an $\mathrm{A}^{+}$-rated borrower eventually resulted in the transaction being changed to a secured loan).

207 This view is consistent with the results of my study. The only company in my sample that has a substantial amount of long-term unsecured debt is a Fortune I0o manufacturer with an AA credit rating. See Kimmins Interview, supra note 67 (transcript at 3-4); see also CAREY, PROWSE, REA \& UDELL, supra note I4I, at $17-19$ (concluding that borrowers that are "information problematic" sometimes cannot obtain long-term debt and instead must "give up an equity interest in the firm").

208 See, e.g., Edlund Interview, supra note ro2 (transcript at 7) (statement of the corporate borrowing manager for an $\mathrm{AA}^{+}$-rated computer company) (explaining that one of the factors limiting his company's long-term debt is the market's perception that technology companies face significant risks over long periods of time). 
ers often not retain a security interest in the goods that they sell?209 Jackson and Kronman, for example, have argued that trade creditors are so knowledgeable about their customers that they have no need for a security interest. ${ }^{210}$ Kripke tried to explain that same relationship when he argued that third-party financing is the only practical way to provide for prompt payment of suppliers in situations in which the ultimate consumers purchase on credit. ${ }^{211}$

These discussions are flawed because they fail to make any serious attempt to discover whether and when suppliers actually retain security interests. ${ }^{212} \mathrm{My}$ interviews with several players in the inventorysupply market strongly suggest that the pattern that prior scholars have tried to explain does not in fact exist. Rather, a significant (and apparently growing) portion of sophisticated suppliers do retain security interests in the materials that they sell. For example, two different credit officers at a multibillion dollar asset-based financier assured me that the retention of security interests by inventory sellers is not uncommon. ${ }^{213}$ Similarly, a credit executive for Hewlett-Packard said that her company has a practice of taking security interests from its customers, especially high-volume retailers. ${ }^{214}$ Finally, the director of

209 Jackson and Kronman do not expressly argue that trade creditors never retain a security interest. They do argue, however, that allowing a bank that lends to the purchaser to have priority instead would be efficient for the parties. See Jackson \& Kronman, supre note 5, at I160-61. Other scholars, however, have claimed that trade creditors in fact do not retain security interests. See, e.g., Buckley, supra note 12, at 1441-42; LoPucki, supra note 8, at 1936, 1941-43.

210 See Jackson \& Kronman, supra note 5, at I160-61. This explanation has been strongly criticized on the ground that trade creditors are not sophisticated monitors. See Buckley, supra note I2, at I44I-42; Schwartz, supra note 5, at II n.28.

211 See Kripke, supra note 15, at 941-46, 959-60; see also Interview with James C. Meals, Director, Portfolio Credit, Deutsche Financial Services Corporation (formerly known as ITT Commercial Finance Corporation), in St. Louis, Mo. (July ro, r995) (hereinafter Meals Interview] (transcript at 3-4, on file with the Harvard Law School Library) (explaining how his company's loans to retailers "provid[e] the manufacturer improved cash flow").

212 Other scholars have noticed this problem. See Kripke, supra note I5, at 944-45, 960 n.r ro; LoPucki, supra note 8, at 1894. The lack of data has not stopped those scholars, however, from proceeding to attempt to explain the hypothesized pattern. See Kripke, supra note 15, at $94 \mathrm{I}-46$, 959-60 (arguing that the pattern rests on the benefits of purchaser financing); LoPucki, supra note 8 , at $194 \mathrm{I}-43$ (attributing the pattern to the refusal of the purchaser's lender to permit subordinate financing).

213 See Greco Interview, supra note 67 (transcript at 6-8) (discussing the retention of security interests by major tire manufacturers such as Michelin, Dunlop, Kelly-Springfield, and PirelliArmstrong); Meals Interview, supra note 2II (transcript at 4-7) (discussing the retention of security interests by a large agricultural manufacturer, Sharp, and by Sony, RCA, and Apple on some accounts).

214 See Dunn Interview, supra note 67 (transcript at 3-5). This executive also said that most of the suppliers in her industry had similar credit practices. See id. (transcript at 5-6). She further explained that, even in the cases in which Hewlett-Packard would accept a position subordinate to the position of a finance company (such as Deutsche Financial Services), HewlettPackard ordinarily would insist that the finance company guarantee payment of the invoice. See id. (transcript at 7). As a result, Hewlett-Packard's subordinate position would not leave it ex- 
credit for a multinational battery supplier told me that his company had started an "experimental effort with new accounts" and was having "very good success" in persuading new customers to grant security interests. ${ }^{215}$

The important question, then, is not why inventory suppliers never retain security interests (because they do), but why some suppliers retain security interests when others do not. ${ }^{216}$ This question is qualitatively different from the questions treated in the preceding two sections, because it assumes that the credit at issue (the credit extended to allow a retailer to purchase inventory) will be secured by at least one party and then asks how the parties determine who will get the first priority. Thus, the relevant decision is more complicated than the decisions considered above: the borrower must decide whether to purchase the inventory without granting a lien at all, whether to grant a lien to the supplier, or whether to grant a lien to a lender that advances funds to pay the supplier on the borrower's behalf. Moreover, the available empirical evidence for this question does not contain the kind of general correlation that appears in the empirical evidence on the strong-borrower and long-term problems. Rather, the empirical evidence here suggests that the factors influencing the decisions of borrowers differ significantly from industry to industry. ${ }^{217}$

Although my interviews provide evidence that suggests some general factors, my evidence is not sufficient to explain the entire pattern. Accordingly, the contribution of this Article is more limited for this

posed to a risk of loss if the customer became insolvent and the finance company took the inventory in satisfaction of its loan. See id. (transcript at 8).

215 Wirengard Interview, supra note 65 (transcript at 3 ).

216 I did speak to representatives of two inventory suppliers that do not retain security interests in inventory that they sell. Both companies, however, are large, publicly traded manufacturers that have small credit losses. One explained: "We have very good credit experience. We have obviously some bad debt expense, every company does, but it's really at a very, very low level relative to the spread of risk that we have in our receivables portfolio. It's quite acceptable." Manufacturer Treasurer Interview, supra note 54 (transcript at 8). The other one indicated that "[c]redit losses for my company are practically nonexistent." Kimmins Interview, supra note 67 (transcript at 14). He went on to explain two mechanisms other than security interests that protect the supplier. First, his company conducts annual credit evaluations of its distributors before selling product to them. See id. (transcript at ${ }^{5}$ ). Second, his company arranges to collect the price of the inventory by a prearranged debit transfer that typically occurs no more than nine days after each shipment. See id. (transcript at $\mathrm{I3}_{3}-15$ ).

217 See Greco Interview, supre note 67 (transcript at 17-18) (suggesting that the practice of retaining security interests differs on an industry-by-industry basis); Wirengard Interview, supra note 65 (transcript at 2) (stating that his company's credit terms differ depending on the line of business of the purchaser); $c f$. Dunn Interview, supra note 67 (transcript at 2) (explaining that her company's credit terms are "geography driven," responsive to the custom of local markets); Edlund Interview, supra note Io2 (transcript at 9) (echoing Dunn's comments, with particular reference to southern Europe); Mitchell A. Petersen \& Raghuram G. Rajan, The Benefits of Lending Relationships: Evidence from Small Business Data, 49 J. FIN. 3, 22 (I994) (empirical study showing the statistical significance of line of business to credit patterns). 
puzzle than for the others. The most that I can do is to suggest two factors gleaned from my interviews that seem to drive the securedcredit decisions in some inventory-supply contexts.

The first significant factor is the extent to which suppliers use security as a pricing tool. It is no surprise to hear suppliers say that the "terms [on which they extend credit] are considered to be part of pricing" and that the extent of price competition for a particular sale is a significant factor in the determination of credit terms. ${ }^{218}$ The grant of security is relevant to the supplier only because that grant increases the likelihood that the purchaser will pay for the goods that it purchases, which indirectly increases the effective price that the supplier receives for the sale. Thus, a grant of security is functionally identical to an increase in the premium charged for deferred payment: both indirectly alter the effective purchase price.219 Accordingly, in situations in which price competition calls for discounting to maintain the volume of sales, suppliers should be less concerned about receiving payment of the full nominal purchase price and thus more willing to sell unsecured, even when there is some cognizable chance that they will not be repaid.

The second factor arises from the mechanics of distributing the supplier's products. Specifically, my evidence suggests that a manufacturer will be more likely to retain security in industries in which dealers purchase inventory from only a small number of manufactur-

218 Wirengard Interview, supra note 65 (transcript at 2); see also Petersen \& Rajan, supra note $2 \mathrm{I} 7$, at $20 \mathrm{n.I7}$ (discussing the relation between a manufacturer's pricing flexibility and the terms of credit that it offers); Dunn Interview, supra note 67 (transcript at 10) (describing credit as "much more a part of the sales process than it is part of the finance function").

219 Lynn LoPucki has suggested that suppliers do not alter their credit terms to account for the riskiness of a purchaser, arguing that suppliers protect themselves instead by "cash-flow surfing" - monitoring the borrower's performance as reflected in credit reports. LoPucki, supra note 8, at I935-36, I94I-43. Bebchuk and Fried share this view. See Bebchuk \& Fried, supra note 7I, at 886-87. As explained in detail in earlier discussion, LoPucki errs in arguing that unsecured lenders to small businesses can protect themselves by monitoring credit reports. See supra notes 65-67 and accompanying text. LoPucki also errs to the extent that he suggests that the credit terms offered by suppliers do not take account of the riskiness of the purchasers. Inventory suppliers have several ways to discriminate based on the creditworthiness of their customers. First, suppliers can insist on cash payments from purchasers of doubtful financial strength. See Petersen \& Rajan, supra note 217 , at 23 (indicating that larger and older firms are more likely to purchase on credit); see also Dunn Interview, supra note 67 (transcript at 3-4) (describing the care with which Hewlett-Packard assesses the amount of credit to extend to customers). Second, because weaker firms are much less likely to take advantage of discounts for prompt payment, inventory suppliers effectively charge much higher interest rates to weak credits than they do to strong credits. See Petersen \& Rajan, supra note 217 , at 25. Third, and most important for this Article, suppliers use collateral to protect themselves against the risk of selling to weaker purchasers. See, e.g., Wirengard Interview, supra note 65 (transcript at 3) (explaining that his effort to take security interests from new accounts is focused on "smaller, riskier" accounts); id. (transcript at 7) (explaining that most secured accounts involve customers that do not "hav[e] strong finances"). 
ers and will be less likely to retain security in industries in which dealers purchase inventory from a large number of manufacturers. If a dealer purchases all of its inventory from a single manufacturer, manufacturer financing would be just as cost-effective as dealer financing: in either case there would be only a single financing transaction for each dealer. Although manufacturers are not traditionally viewed as sophisticated lenders, my interviews suggest that manufacturers are just as capable of monitoring the condition of their retail customers as are the more visible asset-based institutional lenders who engage in the same type of lending.220 For example, the director of credit for a major battery supplier explained that the retention of security interests by manufacturers is uncommon in many industries due to the impracticality of requiring each of the suppliers of a major retail purchaser to file financing statements in each of the jurisdictions in which the purchaser has operations. ${ }^{221}$ Conversely, the same individual also explained that his company was much more successful in retaining security interests from purchasers "where someone may depend largely on our product," explaining that "the larger our presence, the greater our opportunity of having [security] agreements completed and signed."222 Thus, although I argue above that filing costs do not generally influence the decision whether to grant collateral, the multiplesupplier scenario presents a situation in which filing costs can have a dispositive effect.

The two factors that I have identified do not explain all of the instances in which suppliers retain security interests. For example, some of my interviews indicated that suppliers retain security interests from dealers who purchase from multiple manufacturers. ${ }^{223}$ Furthermore, relevant incentives other than the two discussed above clearly exist. ${ }^{224}$ The problem, of course, is that the lack of information about

220 See Meals Interview, supra note 2 II (transcript at 4-5) (explaining how suppliers that retain security interests "utiliz[e] the same types of management techniques that are involved in inventory financing [including] inventory audits . . . and so forth"); Wirengard Interview, supra note 65 (transcript at 6) (explaining that the lighting products division of General Electric has "a full department of people" to monitor financing that the company extends to its customers).

221 See Wirengard Interview, supra note 65 (transcript at 7).

222 Id.

223 See Dunn Interview, supra note 67 (transcript at 5-6) (describing the use of this arrangement in the computer industry); Greco Interview, supra note 67 (transcript at $7-8$ ) (describing the use of this arrangement by tire manufacturers, which frequently use nonexclusive dealers); Meals Interview, supra note 2 II (transcript at 5-6) (describing the use of this arrangement by an agricultural equipment supplier that used $20 \%$ exclusive dealers and $80 \%$ nonexclusive dealers).

$224 \mathrm{My}$ interviews offered some other possible characteristics of industries that might lead suppliers to retain security interests. For example, one asset-based financier suggested that the suppliers that retain security interests in all or most of their products tend to be the suppliers that sell big-ticket items (such as copiers and agricultural equipment). See Meals Interview, supra note 2 II (transcript at 6). A second lender at the same company suggested that suppliers tend to retain security interests not necessarily in big-ticket items, but in items that turn over slowly. See Greco 
the types of suppliers that retain security interests makes a full explanation of the entire pattern impossible. My analysis does, however, offer an explanation for the failure of suppliers to retain security interests more broadly and for some of the most obvious circumstances in which suppliers retain security interests. This explanation is a considerable advance over the prior scholarship, which has endeavored to explain a pattern without stopping to determine whether the pattern in fact exists.

\section{CONCLUSION: WhERE DO WE GO FROM HeRE?}

This Article will not be the last word in the debate about the reasons for secured credit. I do hope, however, that it advances the general terms of the debate. In particular, I hope that it illustrates the importance of empirical and contextual analysis of secured credit. As this Article demonstrates, efforts to evaluate secured credit from a broad theoretical perspective frequently produce explanations and predictions that are inconsistent with the basic facts about the actual pattern of lending. For example, the evidence presented in this Article casts serious doubt on prior claims in the literature that lenders use secured credit to cement exclusive lending relationships, that lenders to small creditors use credit reports to monitor the day-to-day operations of their borrowers, and that secured credit imposes no significant transaction costs. Articulation of an abstract theory, however elegant it may be, is not useful if the theory does not rest on a firm empirical foundation. Because this Article's analysis is coupled with empirical evidence, it provides a base of knowledge that can aid future scholars whether or not they accept the conclusions presented here.

Furthermore, this Article shows the importance of attention to context. Secured credit is an area in which broad conclusions are likely to be incorrect: suppliers do not always lend on an unsecured basis, and large companies do not always borrow unsecured. To make a serious effort to describe the richness of the real pattern, a theory must not only acknowledge, but embrace, the variety of the circumstances in which parties make lending decisions. This conclusion may frustrate those who search for a single unifying theory for credit decisions. But a complicated theory with explanatory value is preferable to a simple and unitary theory that bears no relation to the actual world of lending.

Finally, the swirling policy debates about the propriety of secured credit make an understanding of the reasons why commercial borrowers use collateral particularly important. Much of the most prominent

Interview, supra note 67 (transcript at $17-18$ ) (discussing the retention of security interests by tire manufacturers). 
recent scholarship rests on the premise that secured credit ordinarily is motivated by the desire of borrowers to limit the pool of assets available to pay small and involuntary creditors, thus lowering the cost that borrowers incur for the credit extended by those "nonadjusting" creditors. $^{225}$ This scholarship suggests that secured credit does not produce a benefit, because any costs that the borrower saves are shifted to the creditors who are at risk of going unpaid. ${ }^{226}$

Yet none of these scholars has offered any substantial empirical evidence that these considerations in fact motivate the structuring of commercial lending transactions. This Article, in contrast, presents a detailed analysis of the mechanisms by which secured credit provides borrowers with benefits that are wholly distinguishable from the costshifting benefits condemned in the existing scholarship. Specifically, secured credit lowers the costs of lending transactions not only by increasing the strength of the lender's legal right to force the borrower to pay, but also by enhancing the borrower's ability to give a credible commitment to refrain from excessive future borrowing and by limiting the borrower's ability to engage in conduct that lessens the likelihood of repayment. Although my analysis cannot disprove the significance of prejudice to nonadjusting creditors through cost-shifting, ${ }^{227}$ this Article does provide an alternative explanation that has a significant empirical basis and considerable explanatory power. The power of my explanation for secured credit suggests that policymakers should pause before proceeding with reforms ${ }^{228}$ predicated on the absence of any legitimate justification for secured credit in commercial borrowing. Law reform efforts would be much more productive if they focused on solving the problems that prevent effective contracting in practice rather than on eradicating problems that are likely to be more theoretical than real.

225 See Bebchuk \& Fried, supra note $7 \mathrm{I}$, at 89I-95; see also LoPucki, supra note 16 , at 14 (describing debtors' use of secured debt as the "most complex and the most common of the judgment-proofing strategies").

226 See, e.g., Bebchuk \& Fried, supra note 71, at 896-97.

227 Indeed, in other work I have argued that empirical evidence can demonstrate that such a problem exists in the financing of construction projects. See Mann, supra note 45 , at $3 \mathrm{I}-42$.

228 See, e.g., Bebchuk \& Fried, supra note 71 , at 909-II, 913-34 (proposing a fixed-fraction priority rule that would limit secured status to a fixed fraction of the amount of the debt, in the range of 75\%); Memorandum from Elizabeth Warren, Professor, Harvard Law School, to Council of the American Law Institute (Apr. 25, 1996) (on file with the Harvard Law School Library) (proposing to limit secured status to $80 \%$ of collateral value). 